\title{
A Segunda Escravidão e a Primeira República Americana
}

The Second Slavery and the First American Republic

\author{
Edward E. Baptist \\ Professor no Departamento de \\ História da Cornell University \\ (Ithaca/EUA) \\ e-mail: eeb36@cornell.edu
}

\section{Resumo}

Este artigo reescreve a história dos Estados Unidos antes da Guerra Civil, tomando por base quatro fases de sua história financeira. Essas fases mapeiam os ciclos cambiantes de boom and bust, movidos pelos anseios dos empresários em expandir a escravidão por meio de um sistema financeiro inovador e desregulado. A habilidade dos escravizadores em usar o Estado para formar os mercados, extrair rendas, subscrever os fluxos de crédito da comunidade mundial de investidores e socializar as perdas, ao mesmo tempo em que aumentavam constantemente a produtividade da escravidão nos campos de algodão, foi a força motora que ditou a expansão mais ampla economia norte-americana e suas crises periódicas.

\section{Abstract}

This article rewrites the history of the Antebellum United States around the four phases of its financial history. These phases map out changing boom-and-bust cycles, driven by the entrepreneurs' desire to create innovative and deregulated financing of the expansion of slavery. The ability of enslavers to use the state to create markets, extract rents, underwrite credit flows from the worldwide community of investors, and socialize losses was the main driving force for the broader expansion of the U.S. economy and for its periodic crises as well.

\author{
Palavras-chave \\ Estados Unidos, escravidão, história financeira \\ Keywords \\ United States, slavery, financial history
}


Em 1841, um negro livre chamado Solomon Northup recebeu uma oferta irrecusável. Eram tempos dificeis aqueles. Em Saratoga Springs, um recanto a um dia de viagem da cidade de Nova York pelo rio Hudson, uma queda nacional do poder de compra atingiu especialmente os donos de pensões e artistas. Northup vivia parte como carpinteiro, parte como violinista, portanto nenhuma de suas habilidades valiam muita coisa naquele momento. Com uma esposa e três filhos para criar, ele ficou aliviado com a proposta de se juntar a um pequeno circo de Washington D.C. que fazia uma turnê pelo nordeste dos EUA. Seu trabalho seria tocar seu violino por alguns meses. Sim, ele ficaria longe de sua família, mas ao menos voltaria com dinheiro suficiente para que sobrevivessem durante todo o inverno do ano seguinte. Talvez a economia se normalizasse e nova-iorquinos ricos voltassem a gastar dinheiro com as belezas de Springs e não mais com advogados para cuidarem de suas falências.

Northup aceitou o trabalho e viajou com seu empregador para Washington. Chegando lá, o sujeito o levou para uma noite de bebedeira e Northup logo passou mal. Quando acordou, viu que estava acorrentado em um barracão em Washington. Ele tentou convencer o homem que dizia ser seu dono - James Burch, proprietário de uma firma envolvida no comércio de escravos em parceria com Theophilus Freeman de Nova Orleans - de que era livre, mas este apenas riu. Solomon, argumentou Burch, era mais um escravo fugido da Geórgia que havia sido capturado e vendido para ele e Freeman. Um dos empregados de Burch tirou, então, toda a roupa de Solomon, o espancou com um pedaço de madeira e o açoitou com um chicote de tiras até deixá-lo inconsciente.

Os doze anos seguintes foram como um longo pesadelo. Os traficantes de escravos levaram Northup para outro barracão em Richmond e posteriormente o enviaram para Nova Orleans de navio com outras pessoas escravizadas. Ele estava escravizado em todos os sentidos e desse modo aprendeu que, nos Estados Unidos, seu direito à liberdade era apenas um acidente geográfico. Presumia-se que pessoas de ascendência africana eram escravas e disso dependia toda a economia política. Vendido em Nova Orleans, ele foi enviado para a região de Red River na Louisiana. Seu novo dono tentou ensiná-lo a colher algodão, a tarefa mais importante na gigantesca máquina que se estendia das Carolinas ao Texas. A colheita era a parte mais lenta da produção do algodão bruto, a mercadoria mais negociada do mundo. Seu preço estabelecia outros preços e fornecia a matéria bruta da Revolução Industrial então em curso. Escravistas forçavam mãos como as de Northup a coletarem cada vez mais algodão todo ano. Ainda que excelente tocando violino, suas mãos eram desajeitadas com as fibras. Por causa delas ele apanhou muito. Em outras ocasiões, escravistas bêbados tentaram matá-lo. Solomon presenciou a tortura sexualizada de mulheres por seus escravizadores, a lenta morte de mães cujos filhos foram vendidos para outras paragens e a fria distância de seus companheiros de trabalho, receosos com a vulnerabilidade que laços mais fortes poderiam acarretar.

No entanto, Solomon teve alguma sorte: seu dono, desesperado com o estado de suas finanças, hipotecou-o para outro homem na mesma vizinhança. Ser hipotecado geralmente não ajudava escravos, mas os anos de 1841-1842 foram marcados por um grande caos financeiro na fronteira escravista do algodão e tudo então parecia possivel. Duas crises ocorreram em 1837 e 1839, quando o dinamismo econômico dos estados e territórios produtores de algodão do Sudoeste geraram uma imensa bolha especu- 
lativa nos preços de escravos. Toda a região escondia um grande volume de dividas impagáveis. Todos os homens brancos locais deviam uns aos outros e para gente de fora - bancos e comerciantes - enquanto os preços do algodão permaneciam muito baixos para que qualquer um deles meIhorassem suas posições. 0 futuro era incerto tanto para Solomon quanto para os outros escravos, cujas posições estavam indefinidas por terem sido usados como instrumentos da onda de expansão e inovação financeira a partir da década de 1830. Eles poderiam ser levados de um lado para outro como subterfúgio para se evitar a cobrança de dívidas, vendidos por alguns trocados na escadaria do fórum ou enviados rapidamente ao Texas por escravizadores endividados demais para conseguirem sanar suas dívidas.

No caso de Solomon, o fato de ser propriedade de muitas pessoas o protegia. Seus donos deviam dinheiro em uma rede que se estendia além do Atlântico e envolvia milhares de investidores britânicos, holandeses, alemães e franceses que haviam comprado debêntures relacionadas aos lucros gerados pelas dezenas de milhares de escravos da Louisiana. Além disso, William Ford, uma figura local que possuía uma garantia hipotecária em "Platt" - como os traficantes haviam rebatizado Solomon - não podia se dar ao luxo de perder um de seus bens mais lucrativos. Quando um branco embriagado ameaçou bater em "Platt", Northup pegou seu chicote e virou a mesa. 0 homem voltou com amigos armados, prontos para assassinarem Solomon. Mas um feitor interveio, insistiu que seu empregador tinha uma garantia hipotecária de quatrocentos dólares em Solomon e que seria impossivel para o credor recuperar seu dinheiro com um cadáver.

Solomon então viveu por mais uma década na vizinhança de Bayou Boeuf, logo ao sul do Red River. Durante vários anos pensou que talvez morreria lá também. Ele conseguiu, no entanto, enviar uma carta escondida para um nova-iorquino branco, um ex-empregador e patrono cujo pai havia sido dono de seu pai. Esse homem foi até a Louisiana, encontrou "Platt" e comprovou sua verdadeira identidade. Após doze anos, Solomon era Solomon novamente, tudo em um dia. De modo um pouco brusco, já que nunca havia realmente aceitado que seus companheiros escravos fossem seus iguais, deu adeus aos homens e mulheres que estiveram com ele durante todo aquele tempo. Northup retornou para sua familia: sua esposa era então uma senhora de meia idade, sua filha de sete anos estava com dezenove e recém-casada. Em busca de algum dinheiro, ele escreveu sua autobiografia, que foi imediatamente promovida por organizações antiescravistas e jornais que circulavam entre os ávidos leitores nortistas, irritados com a Slave Fugitive Act [Lei do Escravo Fugitivo] de 1850. Essa lei - demandada por escravistas sulistas como forma de afirmação dos direitos constitucionais que tinham sobre seus escravos, direitos estes que transcendiam as fronteiras estaduais e que, de acordo com a Suprema Corte, deveriam ser respeitados tanto pelos estados livres quanto pelos escravistas - permitiu o surgimento de versões legalizadas do sequestro de Northup. Sua narrativa, intitulada Twelve Years a Slave, rapidamente se tornou um clássico abolicionista, alcançando a marca de 27.000 cópias vendidas nos dois anos seguintes à sua publicação em 1853. 0 livro concluía com as expectativas de Northup: "graças ao bom Deus, cuja misericórdia me devolveu a alegria e a liberdade, eu espero levar daqui em diante uma vida honesta e humilde". Fiel às práticas do crescente movimento abolicionista, ele viajou por diversas cidades no interior do Norte, promovendo seu livro e políticas contra a expansão da escravidão por 
NORTHUP, Solomon. Twelve years A Slave: Narrative of Solomon Northup, a Citizen of New York. Buffalo, NY: Derby, Orton and Mulligan, 1853. p.321; NICHOLS, Charles H. Who Read the Slave Narratives. Phylon, n.20, 1959, p.149-162.

2

St. Albans' (Vt.) Messenger, 11 de dezembro de 1856. FISKE, David. Solomon Northup: His Life Before And After Slavery. Prelo, 2012.

3

Variety, 11 de novembro de 2011, http://variety. com/2011/film/news/fassbender-mcqueen-reteam-for-slave-1118044258/ (acessado em 20 de março de 2013). meio de palestras para públicos compostos por jovens mulheres determinadas e seus respectivos. Desde a década de 1830, um pequeno, porém barulhento, movimento abolicionista tentava motivar brancos nortistas a agirem contra a escravidão sulista. Tais ativistas não apenas falharam, mas foram excluídos, ridicularizados e até mesmo espancados. Alguns nortistas não-abolicionistas, no entanto, começaram a se preocupar com as infindáveis demandas sulistas pela expansão da escravidão - e a recusa de sulistas em pagar suas dividas havia contribuído para os pânicos de 1837 e 1839. Abolicionistas mais antigos haviam rejeitado a via política eleitoral, pois ela estava totalmente comprometida pelos dois principais partidos, Whigs e Democratas, cujas alianças inter-regionais se escoravam em um acordo mútuo de manter o silêncio acerca da escravidão. ${ }^{1}$

A política de dois partidos viria a se mostrar menos simples do que se esperava. Democratas nortistas e Whigs relutavam em juntar suas forças contra sulistas, que vinham habilmente manipulando o sistema bipartidário por gerações. Em 1854, Democratas do Sul convenceram o senador de Illinois Stephen Douglas e o presidente Franklin Pierce, nascido em New Hampshire, a passarem o Ato Kansas-Nebraska, que permitiu a expansão da escravidão em um território de 250.000 milhas quadradas nos campos norte-americanos, fechados até então pelo Compromisso do Missouri. Enquanto isso, um jornal de Vermont dizia que Solomon Northup tinha vindo à cidade para dar uma "exibição moral" - uma palestra baseada nos temas de sua autobiografia - mas que ele e seus amigos "ficaram bêbados e tiveram uns bons momentos que acabaram em pancadaria... Solomon deixou a cidade no dia seguinte"2.

A história de Northup tem inegáveis toques dramáticos. Em 1984, 0 famoso fotógrafo Gordon Parks dirigiu um filme para a TV baseado em sua memória, estrelando Avery Brooks como Solomon. Adepero Oduye (graduado da Universidade de Cornell) e Brad Pitt foram escalados para estrelarem uma versão de Twelve Years a Slave, dirigido por Steve McQueen e em estágio de pré-produção em 2012. ${ }^{3}$ Ainda assim, na década de 1850, a despeito das políticas de terra livre - isto é, políticas que se opunham à expansão da escravidão - defendidas pelos contemporâneos de Northup nos estados livres, jornais nortistas se mantinham altamente céticos em relação às reclamações do ex-escravo. Tais publicações se apressavam em representá-lo como ridículo e traiçoeiro. Não que duvidassem de sua história, apenas não queriam ouvi-la. Solomon Northup apresentou seu caso como um erro de categoria, o deslize filosófico que ocorre quando coisas de um tipo (cidadãos livres) são apresentadas como coisas de outro tipo (escravos). 0 conto do negro livre nortista que foi sequestrado e transformado em escravo deveria operar como uma espécie de sinédoque no qual o leitor chegaria à conclusão de que todas as pessoas escravizadas haviam sido, na verdade, roubadas. Mas não foi isso que aconteceu. Como autor e como personagem, Northup esbarrou nos obstáculos estabelecidos por duas realidades impostas a todos os afro-americanos. Esses dois fatos modelaram toda a história americana de 1780 a 1861.0 modo como eles quase destruíram a vida de Solomon Northup era uma constante, não uma exceção. Entretanto, esses fatos não são descritos como tal na maioria das histórias dos EUA. Eu os nomearei aqui. 0 primeiro se chama Segunda Escravidão. 0 segundo nós chamaremos de Primeira República.

Os dois fatos jogam um papel fundamental no livro que estou terminando e no qual se baseia o presente artigo para a Almanack. A obra, sob 
4

POMERANZ, Kenneth C. The Great Divergence: China, Europe, and the Making of the Modern World Economy. Princeton, N.J: Princeton University Press, 2000.
TOMICH, Dale W. Through the Prism of Slavery. Labor, Capital, and World Economy. Boulder: Rowman \& Littlefield, 2004 contrato com a Basic Books, se chamará The Half That Has Never Been Told: The Forced Migration That Shaped U.S. History, African-American History, and the World [A metade que nunca foi contada: a migração forçada que modelou a História dos EUA, dos afro-americanos e do mundo]. Nela, argumento que a migração forçada de afro-americanos escravizados para as fronteiras da escravidão foi o motor da história dos EUA entre a Revolução e a Guerra Civil. Desse processo surgiram todas as mudanças importantes e com ele permaneceram todas as estruturas estáveis do velho Sul. Ao longo dos setenta e poucos anos passados entre os debates constitucionais dos anos 1780 e o início da Guerra Civil, a escravidão nos EUA expandiu vertiginosamente. Ela cresceu de 800.000 cativos para quatro milhões, e de uma estreita faixa litorânea composta por fazendas em declínio para um território do tamanho de um subcontinente marcado por fábricas no campo; campos de trabalho escravo cuja produtividade por trabalhador expandia a cada ano. A expansão da escravidão nos EUA formou o país, em grande parte por ter extraído o máximo possivel do principal produto da Revolução Industrial: algodão, o seu petróleo, sua mercadoria mais negociada, a mais importante e maior definidora de preços. Como argumenta o historiador econômico Kenneth Pomeranz, sem essa expansão não haveria qualquer Revolução Industrial - não haveria a fonte inesgotável de fibras para as tecelagens de Manchester e Lowell poderem tecer o produto manufaturado central da era das fábricas. ${ }^{4}$

0 livro começa, termina e mantém em seu centro a experiência de pessoas escravizadas como Solomon Northup. Os traumas pelos quais passaram os deixaram com algumas poucas opções sombrias: morrer ou render-se, adaptar-se e alienar o próprio corpo ou resistir e ser submetido à tortura. 0 modo pelo qual a cultura, família e religião afro-americanas se adaptaram a esse contexto forma boa parte do livro, bem como os comentários e análises das pessoas escravizadas a respeito desses processos enquanto história, uma experiência comum que influenciou a todos. Neste artigo, contudo, deixarei de lado essas e outras questões que exploro ao longo do livro. Pretendo me concentrar especificamente em dois fenômenos - um de movimento, dinamismo e dialética, outro de estrutura - um de economia, outro de política - que moldaram todas as experiências e processos de migração forçada.

Os dois fenômenos em questão são a Segunda Escravidão e a Primeira República. Comecemos pela Segunda Escravidão, um termo que não cunhei, mas que representa um processo mais amplo do qual os EUA foram um dos casos mais importantes. ${ }^{5}$ Irei me dedicar particularmente às inovações financeiras que se encontravam no coração do crescimento da Segunda Escravidão, ao menos nos EUA. Se havia, no entanto, uma Segunda Escravidão, qual foi a primeira?

A primeira escravidão nasceu da expansão da primeira rede imperial europeia. Impérios mercantilistas transplantaram das ilhas atlânticas para o Brasil e ilhas caribenhas o modelo de engenho operado por africanos importados. Surgiram, assim, colônias de tabaco como a Virgínia e Cuba, que mantiveram os cofres de seus impérios abastecidos. Acima de tudo, os triângulos de comércio entre fortalezas negreiras africanas, casas contábeis europeias e as "ilhas que se repetem" enriqueceram um pequeno, porém crescente, grupo de burgueses: comerciantes, banqueiros, advogados. Lentamente eles acumularam os ganhos produzidos por suor, sangue e caldeirões em ebulição. Eles eram mais ricos do que seus antecessores jamais 
BLACKBURN, Robin. The Making of New World Slavery: From the Baroque to the Modern, 14921800. London: Verso, 1997.

7

DAVIS, David Brion. The Problem of Slavery in the Age of Revolution, 1770-1823. Ithaca: Cornell University Press, 1975; BLACKBURN, Robin. The Overthrow of Colonial Slavery. London: Verso, 1988; BROWN, Christopher L. Moral Capital: Foundations of British Abolitionism. Chapel Hill: University of North Carolina Press, 2006. haviam sido e remodelavam suas sociedades (se eles fossem à Jamaica e arriscassem uma morte prematura, eles poderiam ter se tornado ainda muito mais ricos. Alguns acumularam o suficiente para retornarem e comprarem seus lugares no Parlamento, abrindo espaço com suas carruagens pelas ruas de Londres em meio aos duques e nabobs). ${ }^{6}$

Apesar de a primeira escravidão ter sido imensa em comparação aos processos de migração transoceânica que a antecederam (carregando, por exemplo, de cinco a seis milhões de escravos através do Atlântico nos setecentos), ela chegou ao fim. Em torno dos anos 1780, surgiu um sentimento, em boa parte oriundo da própria burguesia, de que homens racionais ou pessoas evangelicamente morais não poderiam mais defender a escravidão. Fazendeiros no Sudoeste dos EUA começaram a emancipar seus escravos - sem dúvida auxiliados pela queda nos preços do tabaco - e uma cruzada contra o tráfico atlântico de escravos, que mantinha as colônias de açúcar abastecidas com trabalhadores fadados a uma vida curta, colocou o futuro da Primeira Escravidão em questão. No entanto, o evento por excelência da era foi a impensável, da perspectiva europeia, revolução dos escravizados de Saint Domingue, a última ilha que se repetia. Por treze anos, as pessoas que eram supostamente incapazes de cidadania, bravura ou inteligência, que estavam aparentemente destinadas à escravidão, resistiram e derrotaram de forma extraordinária todos os grandes poderes do mundo. Os fazendeiros creoles, britânicos, espanhóis e, finalmente, um exército francês, treinado e enviado por Napoleão Bonaparte - todos foram vencidos pelos rebeldes que, em 1804, passaram a se chamar de haitianos. Enquanto a explosão da revolução em 1791 silenciou as críticas à escravidão na Grã-Bretanha e nos EUA, seu sucesso seria usado posteriormente pela opinião pública britânica e norte-americana como um alerta para a necessidade de se proibir o tráfico de escravos africanos. Os rebeldes, de acordo com os proponentes das leis antitráfico passadas no Congresso e no Parlamento, eram nascidos, em sua maioria, na África. ${ }^{7}$

Assim, a virada do século dezoito para o dezenove deveria ter marcado a passagem para uma era de esclarecimento, emancipação e progresso racional. 0 que se teve, no entanto, foi capitalismo e nacionalismo, além de, claro, escravidão, que parecia fadada ao desaparecimento em várias partes do mundo Atlântico, mas que floresceu durante a maior parte do século dezenove como plantas venenosas de um novo tipo. Como meu livro demonstra, a escravidão nos EUA teve seu declínio revertido e cresceu vertiginosamente entre 1783 e 1861. Enquanto eu escrevia o livro, meus contatos com colegas trabalhando com processos de expansão escravista semelhantes no século dezenove, em especial no Brasil e em Cuba, aumentaram. 0 que encontramos foi que os Oitocentos foram em sua maior parte um século de expansão da escravidão, que, por sua vez, operou em novas bases. Nos EUA o número de escravos expandiu em 500\% entre a passagem da Constituição e 1860 (principalmente por reprodução natural), quando escravistas tentaram destruir a Constituição. Os números no Brasil e Cuba passaram por crescimentos semelhantes, ainda que nesses casos a expansão tenha se dado através do persistente tráfico transatlântico de escravos. A Primeira Escravidão produziu bens de luxo como açúcar e tabaco para 0 consumo conspícuo de elites, mas que eventualmente se tornariam símbolos da prosperidade burguesa. A Segunda Escravidão produziu mercadoriaschave - no caso do algodão, a principal de todas antes da transição para o carvão mineral como fonte energética a partir dos anos 1840 - para os 
8

OLMSTEAD, Alan; ROHDE, Paul. Biological Innovation and Productivity Growth in the Antebellum Cotton Economy. NBER, Working Paper, n.14142, p.22, junho de 2008. florescentes mercados industriais, que cresciam tão rapidamente, e com um impacto histórico tão grande, que a Revolução Industrial permanece sendo vista como a fronteira entre o mundo moderno e tudo que veio antes.

As mercadorias da Segunda Escravidão eram componentes fundamentais da produção industrial. Mas isso não era tudo. A Segunda Escravidão era culturalmente moderna e economicamente modernizante de outras formas também. Na expansão da escravidão dos EUA, por exemplo, escravistas operando de modo mais flexivel e empreendedor constantemente transformaram e reorganizaram seus negócios. A sofisticação e eficiência tecnológicas aumentavam nos seus campos de trabalho escravo ano após ano. Essa visão contradiz boa parte das visões sobre a escravidão. Um dogma econômico de longa duração insistiu - e continua a insistir - que escravistas e trabalho escravo eram estáticos. Nossos dados, todavia, mostram que as empresas da Segunda Escravidão continuamente aumentaram a produtividade do trabalho, e o fizeram em niveis comparáveis àqueles atingidos por empresas industrializantes de tecelagem e fiação da Grã-Bretanha. De 1800 a 1860, a eficiência do trabalho escravo na colheita de algodão, a parte mais lenta do processo de trabalho, aumentou em $400 \%$. 0 crescimento na eficiência dos trabalhadores da fiação durante o mesmo periodo foi parecido; o trabalho na tecelagem foi maior, mas da mesma ordem de grandeza. As pessoas escravizadas nos campos de trabalho escravo das sociedades da Segunda Escravidão produziram as novas mercadorias de maneiras tão dinâmicas quanto o modo de produção que emergia em Manchester. Na verdade todas essas novas formas de se produzir mercadorias eram parte de uma mesma revolução. ${ }^{8}$

Solomon Northup chegou em Red River no meio do processo de procura incessante pela maior eficiência possivel do trabalho no algodão, e foi nos campos da Louisiana que ele descobriu como os cidadãos brancos da república dos especuladores, que colaboraram em seu sequestro, desfrutavam dos ganhos infinitos em produtividade. Desde a invenção do descaroçador de algodão em 1791, que eliminou parte da lentidão do processo de produção ao criar uma solução mecânica para o problema de separar as sementes das fibras, o aceleramento do processo de produção de algodão bruto aumentava. Pessoas escravizadas podiam ser forçadas pelo que elas vieram a chamar de pushing system [sistema de empurrões], uma forma de conseguir que cultivassem muito mais algodão do que poderiam colher antes do inverno danificar as fibras. A colheita era um trabalho muito difícil, exaustivo. Requeria mãos rápidas, dedos habilidosos e deveria ser feita ao longo de todo o dia. 0 movimento repetitivo dos corpos, exigindo a máxima atenção em uma tarefa entediante, deixava os músculos machucados, os olhos cansados e as mentes completamente exaustas ao fim do dia. As pessoas odiavam catar algodão. Escravistas desenvolveram então um sistema de cotas em que novatos como Northup eram forçados a atingir seu nível máximo de colheita ao longo do dia. Seus cestos de algodão eram pesados ao lado do descaroçador em uma balança romana. Uma vez conhecido o total, o escravista elevava levemente a cota da "mão". Depois ele a escrevia em uma folha de papel ou em um quadro. Se no dia seguinte 0 volume de algodão apanhado não atingisse a cota, então, como no caso de escravos punidos nas fazendas de café brasileiras por não colherem grãos de café o suficiente em um dia, a "mão do algodão" passava por um brutal açoitamento (em alguns casos, para completar a lógica desse sistema de contabilidade, escravistas davam uma chicotada por libra abaixo da cota, 
Leitores vêm ignorando essa realidade extraordinária há mais de um século. Ao longo dos últimos duzentos anos, na verdade, de Adam Smith ou Frederick Law Olmstead à maioria dos historiadores modernos, analistas têm afirmado que a produção agrícola de escravos era menos eficiente que a produção de trabalhadores livres. Mesmo aqueles que mediram a agricultura escravista, como Robert Fogel, que percebeu que as fazendas de algodão eram mais produtivas quando comparadas às fazendas do norte livre, apontaram para o motivo errado. FOGEL, Robert. Without Consent or Contract. New York: Norton, 1989. p.72-80; OLSON, John. Clock Time Versus Real Time: A Comparison of the Lengths of the Northern and Southern Agricultural Work Years. In: FOGEL, Robert W.; ENGERMAN, Stanley L. (org.). Without Consent or Contract: The Rise and Fall of American Slavery. Markets and Production: Technical Papers Volume I. New York: Norton, 1991. p.216-240; FOGEL, Robert W. ; ENGERMAN Stanley L. Explaining the Relative Efficiency of Slave Agriculture in the Antebellum South. American Economic Review, n.67, p.275-296, 1977; METZER, Jacob. Rational Management, Modern Business Practices, and Economies of Scale in Antebellum Southern Plantations. Explorations in Economic History, n.12, p.123$150,1975$. chamando isso de "pagamento" para contrabalançar a "dívida" referente ao algodão que deixou de ser catado ao longo do dia). ${ }^{9}$

Alguns escravos norte-americanos chamavam esse sistema de whipping machine [máquina de bater] e associavam o processo à uma tecnologia de tortura que visava extrair maiores esforços nos campos e muito mais. Quando Northup conseguiu atingir a cota mínima estipulada, o escravista a aumentou. Escravocratas continuamente extraíram criatividade e destreza, em uma espécie de taylorismo autoinfligido antes de Taylor. Foi assim que as cotas mínimas nos campos de trabalho do algodão no Sudoeste subiram de aproximadamente 50 libras por dia durante 1805 para 100 nos anos 1820 e, finalmente, mais de 200 na década de 1850. As cotas não eram as mesmas para todos os escravos: quanto mais rápidos fossem, mais se esperava deles. Quanto mais talentosos, habilidosos e criativos, mais chances eles teriam - como a amiga de Northup, Patsey, que atravessava os campos como uma dançarina, catando rapidamente com as mãos direita e esquerda - de terem suas cotas elevadas para além dos limites do humanamente possivel.

\section{História Financeira}

A história de Northup revela o processo de crescimento interminável da extração de trabalho e inventividade de pessoas escravizadas. Mas assim como a Segunda Escravidão é uma história de inovação por tortura forçada nos campos, bosques e engenhos de regimes escravistas empreendedores, ela é igualmente um conto de criação e destruição financeiras. Solomon Northup foi escravizado por conta das guinadas de uma história mais ampla. Ele se viu preso em uma dialética entre, por um lado, inovações produtivas e tecnológicas de escravistas do Sudoeste e, por outro, o comportamento empreendedor das comunidades financeiras do mundo Atlântico, uma categoria que (é bom lembrar) incluía vários escravistas. É verdade que essas comunidades compreendiam milhares de agentes, mas alguns tinham mais poder para moldar o destino do que outros. Uma das características das finanças é a possibilidade de que pessoas criem e exerçam imensas alavancagens financeiras. 0 crédito transforma as relações normais em dois eixos, um de poder sobre o espaço, o outro sobre o tempo. Inovações e decisões constantemente transferiam o poder sobre eventos de um grupo para outro dentro de comunidades mais amplas, conectadas internacionalmente através de papéis, dívidas, crédito e da mercantilização dos corpos das pessoas escravizadas na produção de algodão e outros itens.

Os processos dialéticos entre inovação financeira e crescente eficiência produtiva, tanto nas fábricas quanto nos campos, ditaram as transformações dos investimentos e dividas. Essas modificações são, de certo modo, o aspecto central da história dos EUA - no sentido de determinar mudanças - durante o período da Segunda Escravidão. Elas explicam como Solomon Northup foi parar em Red River. Descreverei aqui as quatro eras da história financeira da Segunda Escravidão, de 1804 a 1861. Pode-se dizer, em um sentido keynesiano, que esses quatro momentos representaram diferentes equilibrios nas relações entre investidores, empresários, produtores e consumidores no mundo Atlântico. Nota-se, entretanto, que cada equilibrio continha em si mesmo os germes de sua própria destruição - em cada caso um paroxismo de desmoronamento econômico maciço. Dos escombros desses terremotos surgia, em cada caso, um novo mecanismo mergulhado em suas próprias contradições. 
SELLERS, Charles G. The Market Revolution. New York: Oxford University Press, 1991, talvez seja 0 exemplo mais enfático disso.
Vamos parar para pensar por um minuto por que motivo é tão raro ouvirmos historiadores acadêmicos que trabalham com os EUA do século $\mathrm{XIX}$, especialmente pesquisadores da escravidão, falarem de história financeira. Por décadas a história das finanças e negócios tem sido relegada aos porões mais escondidos da história. Empoeirados e exóticos, esses lugares são geralmente frequentados por amadores pouco afeitos aos métodos da história social e cultural. Quem se mete muito com isso corre o risco de ser considerado conservador. Há muitas razões para isso, mas algumas me parecem importantes o suficiente para serem mencionadas. A primeira é que Marx decretou, e toda a história influenciada por ele concordou, que as relações de produção eram, em última instância, o fator determinante da base econômica de uma sociedade. Um paradigma descritivo que focasse menos na linha de produção e mais na mente do capitalista também estava disponivel para historiadores que preferissem causas intelectuais ao invés do determinismo implacável dos modos de produção. Essa é a narrativa de Weber acerca do capitalista puritano, encontrando uma causalidade entre as crenças religiosas calvinistas e a motivação de capitalistas engravatados a acumularem infinitamente. Capitalistas-puritanos também buscaram convencer seus trabalhadores a internalizarem uma autodisciplina. Weber rejeitou explicitamente a ideia de que "capitalistas de cassino" - cujo termo se referia aos agentes do jogo especulativo financeiro, como os empresários que Joseph Schumpeter, ao contrário, trouxe para o centro - eram agentes de transformações. Nem todos os historiadores que exploraram 0 mundo do trabalho, sociedade e cultura baseados na Formação da Classe Trabalhadora Inglesa de E.P. Thompson perceberam seu pseudomarxismo ou seu criptoweberianismo, mas todos certamente herdaram sua perspectiva de que o que acontecia nas altas finanças era irrelevante. Durante as décadas de 1980 e 1990, a Specie Circulare a Bank War foram exploradas por historiadores interessados no que trabalhadores e outros eleitores sabiam a respeito do papel dos bancos a partir de sua herança de conceitos republicanos clássicos ou o que sua obsessão com o dinheiro nos dizia a respeito de seu desconforto cultural em um mundo em transformação que ameaçava os tradicionais papéis de gênero patriarcais. ${ }^{10}$ Tais pistas apontaram para fenômenos interessantes e nos ajudaram a entender como agentes, imersos em lugares e períodos particulares, compreenderam seu mundo e fizeram suas escolhas. No entanto, tais estudos levaram gerações de pesquisadores a concluírem que certas questões, como o papel da Specie Circular no Pânico de 1837, ou os processos de seleção de escravos de Chesapeake pelos traficantes, eram irrelevantes ou estavam fora da área de pesquisa dos historiadores. É uma pena. Como a demografia, epidemias e clima, algumas forças econômicas tem um poder particular de moldar eventos.

Outro elemento-chave que mascarou a importância da história financeira foi que a maioria dos historiadores sociais que tentaram mapear os mundos sociais das Américas e dos EUA durante a era de transformação capitalista o fizeram após a década de 1930. Uma das principais consequências daquela década turbulenta, ao menos nas democracias capitalistas ocidentais, foi a emergência nos EUA (em especial) de políticas administrativas keynesianas que regularam a especulação financeira em nome de um padrão de crescimento mais controlado. Por três décadas essas políticas macroeconômicas geraram alto crescimento, primeiro nos EUA, posteriormente na Europa ocidental. Os resultados na América Latina foram mais ambíguos. Nesse contexto, a atenção dada aos bancos e especuladores, pânicos e 
11

CASSIDY, John. How Markets Fail: The Logic of Economic Calamities. New York: Farrar, Straus and Giroux, 2009; KLEIN, Naomi. The Shock Doctrine:The Rise of Disaster Capitalism. New York: Metropolitan Books/Henry Holt, 2007; BURGIN, Angus. The Great Persuasion: Reinventing Free Markets Since the Depression. Cambridge: Harvard University Press, 2012; PHILIPS-FEIN, Kimberly. Invisible Hands: The Making of the Conservative Movement From the New Deal to Reagan. New York: W.W. Norton, 2009; HODGSON, Godfrey. More Equal Than Others: America From Nixon to the New Century. Princeton: Princeton University Press, 2004; COWIE, Jefferson; SALVATORE, Nick. The Long Exception: Rethinking the Place of the New Deal in American History. International Labor and Working-Class History. n.74, p.3-32, 2008; COWIE, Jefferson. Stayin' Alive: The Last Days of the American Working Class. New York: New Press, 2010

12

E.g. a forma como pesquisadores falavam sobre BALLEISEN, Edward. Navigating Failure: Bankruptcy and Commercial Failure in Antebellum America. Chapel Hill: University of North Carolina Press, 2001, como se o livro explicasse a etiologia e consequências do Pânico de 1837 quando, na verdade, ele explica a forma como negociantes pensaram acerca de falências. bolhas, parecia no mínimo estranha ou relacionada a algum interesse escuso em Wall Street. Esses fenômenos têm sido ignorados. Até mesmo os heróis anarco-capitalistas de Ayn Rand são industrialistas e super-inventores, e não os barões usurpadores que especulavam com papéis.

Em fins dos anos 60, uma convergência de múltiplos fatores - inflação, choques nos preços do óleo, emergência de novos desafiantes à dominação industrial ocidental, aventuras custosas no anticomunismo e o sucesso da longa marcha da direita americana e seus generais Richard Nixon e Milton Friedman - começou a esvaziar os pressupostos que desviavam a atenção de historiadores das inovações e transformações financeiras. As economias latino-americanas foram transformadas em laboratórios do novo capitalismo de cassino às custas das democracias eleitorais, derrubadas onde quer que existissem na América do Sul. Um ataque direitista nas universidades, faculdades e mídia convenceu o mundo de que visões keynesianas da economia estavam ultrapassadas. Fundamentalistas do livre mercado que escreviam sobre um tal de Hayek - oriundo de um planeta onde as variáveis eram apenas números, informações circulavam com perfeição entre todos os atores e externalidades eram irrelevantes para qualquer problema econômico - substituiram figuras como John Kenneth Gailbraith e Paul Samuelson enquanto vozes da razão nas salas de aula, na mídia, no Conselho de Consultores Econômicos e nas diretorias do Banco Central. Com a cobertura intelectual oferecida por figuras como Alan Greenspan e Robert Lucas, e sua enrolações sem sentido acerca de uma utopia de mercado ("contrapartes podem regular a si mesmas... ninguém mais acredita em Keynes"), legisladores financiados por firmas de Wall Street e companhias de energia forçaram a abertura de mercados de bens e capitais ao redor do mundo e removeram as estruturas das leis dos EUA que regulavam bancos. ${ }^{11}$

As práticas possibilitadas pela desregulamentação e globalização financeira transformaram o mundo. Elas rapidamente transferiam capital de um país soberano a outro, disciplinando os estados nacionais a cederem às vontades da manada descontrolada de investidores financeiros. Para liberar mais capital nesse processo, eles desvalorizaram a indústria dos EUA. A manada se movia não apenas por instinto ou indicadores econômicos. Ela era liderada por uma nova elite global em busca de riqueza que se esforçava em dissolver fronteiras, inclusive as de sua própria nação, para se sobreporem às decisões das maiorias soberanas. 0 resultado para o cidadão comum dos EUA foi um esvaziamento da qualidade de vida e do poder de ação política quase tão dramático quanto nos casos da Argentina e do Chile. A diferença é que aquele notou ainda menos o tamanho da mudança em curso.

Enquanto tais mudanças remodelavam o mundo, historiadores do século XIX continuavam trabalhando como se nada houvesse acontecido. Isso ocorria a despeito do fato de que as universidades públicas e privadas nas quais a maioria deles trabalhava, e onde praticamente todos foram educados, eram radicalmente transformadas pela financialização da economia global. A maioria se dedicou, assim, a uma história cultural baseada quase que inteiramente nas ferramentas desenvolvidas pelos primeiros defensores da virada linguística na crítica literária e na antropologia. Muitos estudiosos do século XIX preferiram ignorar qualquer coisa relacionada aos bancos, lucros, perdas, exploração ou extração - exceto em relação a como os atores representavam essas coisas em palavras. ${ }^{12}$ Dois exemplos devem 
ser suficientes. Em princípios dos anos 2000, uma pós-graduanda extremamente inteligente criticou uma semana de história econômica em meu curso sobre os EUA do século XIX e argumentou que, ainda que houvesse estudado a história da tecnologia capitalista, "não estava interessada em história econômica ou números". Eles estão interessados em você, eu disse para mim mesmo, mas não fiquei surpreso. Já em 1998, quando fiz uma palestra em um evento sobre história oitocentista dos EUA, um comentador sugeriu que o que realmente importava não era minha tentativa de demonstrar como o sucesso de escravistas sulistas em lucrar com mercados de capitais mundiais foi responsável pelo Pânico de 1837. 0 que realmente importava era que a oposição implacável de Andrew Jackson aos bancos esteve baseada em sua leitura de textos republicanos clássicos do século XVIII, que culpavam os bancos pela "Bolha dos Mares do Sul". Durante a seção de perguntas e respostas, outro historiador se levantou e informou que Peter Temin já havia dito tudo o que deveríamos saber sobre a estrutura econômica jacksoniana há trinta anos. Não havia necessidade de nos preocuparmos com a macroeconomia da década de 1830 ou com as causas de uma das crises mais destrutivas do século XIX; todas as respostas já estavam lá.

Sempre houve, todavia, o poderoso argumento de o que se passa nas esferas financeiras da economia - os lugares nos quais bancos, especuladores, investidores, empresários, comerciantes e produtores geravam dinheiro através de crédito desde o século XVIII - é essencial para como o capitalismo tem se expandido, em uma revolução sem fim que simultaneamente cria e destrói tudo ao nosso redor e em nós mesmos. Finanças podem rapidamente transportar capital através de fronteiras, e até mesmo no tempo, permitindo àqueles no comando que multipliquem seu próprio poder significativamente. É impossivel escrever um livro sobre a expansão da escravidão nos EUA sem considerar seriamente o papel da história financeira. $\mathrm{Na}$ realidade, a contribuição fundamental das finanças de grande porte para 0 crescimento escravista era evidente antes mesmo do século XIX. Grandes quantias de capital foram necessárias para financiar as centenas de navios negreiros que eram preparados anualmente em portos franceses, holandeses, portugueses e ingleses. Somas ainda maiores eram adiantadas para os escravistas comprarem cativos em portos brasileiros, caribenhos e norte-americanos; para adquirirem as terras a serem trabalhadas (quando não era possivel simplesmente roubá-las de povos indígenas); e para terem acesso aos suprimentos e equipamentos necessários do período de plantio ao de colheita. As maiores quantias de todas eram usadas nas compras de açúcar, tabaco e outros itens produzidos por escravizados. Igualmente importante era o crédito que garantia as colheitas, seu transporte através do Atlântico e sua distribuição, em muitos casos, para os próprios financiadores cujos empréstimos possibilitavam a organização de viagens a partir de portos escravistas como Bristol, Nantes e Salvador, recomeçando continuamente o ciclo. A história de inovação financeira e acumulação na Europa ocidental e suas colônias atlânticas está intrinsecamente ligada à emergência da Primeira Escravidão.

0 sucesso da Primeira Escravidão, de acordo com Robin Blackburn, criou novos instrumentos financeiros e acumulação de capital em larga escala. Parte desse capital se infiltrou no interior de Liverpool no século XVIII e, através de uma rota ou outra, encontrou novas saídas no emergente setor têxtil que gerou uma impressionante transformação econômica em fins 
BLACKBURN, Robin. The Making of New World Slavery... Op. Cit.; cf. MINTZ, Sidney. Sweetness and Power: The Place of Sugar in Modern History. New York: Viking, 1985; BRAUDEL, Fernand. Civilization and Capitalism, 15th-18th Centuries. 3 Vols. New York: Harper \& Row, 1982-1984.
Cf. GUDMESTAD, Robert. A Troublesome Commerce: The Transformation of the Interstate Slave Trade. Baton Rouge: Louisiana State University Press, 2003; KAMENSKY, Jane. The Exchange Artist: A Tale of High-Flying Speculation and America's First Banking Collapse. New York: Viking, 2008 daquele século. Esse foi apenas um dos meios pelos quais o emergente setor bancário e os mercados financeiros do ocidente - utilizando estratégias de crédito desenvolvidas ao longo de séculos por comerciantes de longa distância e o capital acumulado com extrações nos dois lados do globo - ajudou a arar 0 solo e plantar as sementes da Primeira Revolução Industrial. ${ }^{13}$

Inovações financeiras seriam ainda mais importantes para o imenso crescimento escravista nos EUA pós-Revolução Americana, expansão esta que iria reciprocamente dominar a história financeira do mundo ocidental por toda uma era. A emergência de um setor têxtil britânico, já evidente na crescente demanda por algodão na década de 1780, começava a estabelecer os mercados que possibilitaram a Segunda Escravidão nos EUA. Mesmo antes do conhecido modelo de descaroçador de algodão ter sido patenteado por Eli Whitney em 1791, escravistas dos EUA buscavam lucrar com plantações de algodão no interior da Carolina do Sul e da Georgia. Eles abasteceram seus campos de trabalho fronteiriços com pessoas escravizadas compradas ou transportadas por empresas da Virginia e de Maryland. Essas pessoas eram excedentes para os requerimentos dos escravistas de Chesapeake, em parte porque seus donos - com poucos fundos no ambiente financeiro desorganizado do período entre a Revolução e a passagem da Constituição - precisavam de dinheiro vivo. Produtores de algodão, por outro lado, estavam entre os poucos produtores agrícolas capazes de providenciar fundos imediatos na década de 1780 . Investimentos britânicos eram uma das fontes de fundos na fronteiras da Carolina-Georgia, mas igualmente fundamental era o recém-nascido mercado financeiro nacional. Como no caso de Yazoo, em que estados venderam os direitos às terras na fronteira para companhias especulativas, que posteriormente negociaram títulos dando direito a subdivisões dessas áreas. Isso gerava lucros para os diretores das empresas ao mesmo tempo que estabelecia preços e criava um mercado de terras. Recibos de algodão e terra indicavam a existência de uma demanda a ser preenchida por aqueles que possuiam escravos, e os "homens da Geórgia" (Georgia-men), como as pessoas escravizadas de Chesapeake vieram a chamá-los, já compravam cativos de proprietários sem dinheiro na Virginia e Maryland em torno de 1790 e os arrastavam para serem negociados na fronteira do algodão. A escala dessas empreitadas, bem como do crédito que as financiou, era minúscula comparada ao que viria. Já se notava, entretanto, que essas inovações financeiras - novos instrumentos de crédito ligando fronteiras a investidores, transferência de capital na forma de trabalhadores escravizados, instituições e empresários financiando a aquisição de terras e a produção de mercadorias - estavam dinamicamente ligadas às inovações no trabalho e tecnologia que conectavam as fronteiras da escravidão à expansão industrial. Não foram apenas as transformações na produção têxtil ou no comportamento de seus vendedores e consumidores que controlaram a demanda. Igualmente central foi o fato de que empreendedores escravistas que tiravam vantagem da alavancagem financeira e utilizavam suas propriedades escravizadas como garantia, precisavam expandir a produção para poderem pagar seus novos credores. A exploração do trabalho na Segunda Escravidão combinada com a crescente capacidade de comunidades financeiras ocidentais de levantar fundos para os empreendedores das fronteiras conduziram a oferta de algodão, crédito e a intensidade da tortura extrativista em um gigantesco ciclo recíproco. Talvez fosse isso que os escravos queriam dizer quando ao falar da whipping machine. ${ }^{14}$ 
15

NOLTE, Vincent. Fifty Years in Both Hemispheres: or, Reminiscences of the Life of a Former Merchant. New York: Redfield, 1854; HIDY, Ralph. The House of Baring in American Trade and Finance: English Merchant Bankers at Work,1763-1861. Cambridge, Ma.: Harvard University Press, 1949.

NOLTE, Vincent. Op. Cit.; NORTH, Douglass C. Economic Growth of the United States, 17901860. Englewood Cliffs, N.J.: Prentice-Hall, 1961.
A história da Segunda Escravidão nos permite observar como as inovações financeiras, bolhas e pânicos conduziram as transformações e 0 desenvolvimento da escravidão no século XIX. Vamos então aos quatro episódios prometidos da história financeira pré-Guerra Civil. Em cada período, as relações particulares entre investidores e empresários - muitas vezes, ainda que nem sempre, separados por grandes distâncias - tinham intermediários específicos. Esses intermediários conectavam investidores interessados na expansão do algodão escravista com empreendedores que queriam lucrar mais diretamente com o comércio de pessoas escravizadas ou com aqueles que queriam negociar algodão e outros produtos da Segunda Escravidão. Os intermediários ligando os donos do capital àqueles que queriam utilizá-lo eram, em alguns casos, estruturas organizacionais, em outros, agentes humanos. Alguns eram criaturas mais fantásticas, como instrumentos de crédito. Estes eram pedaços de papel e conceitos que, apesar de terem sido criações humanas, tiveram uma capacidade geradora própria.

\section{Era I}

0 primeiro episódio-chave da história financeira da Segunda Escravidão durou de 1804 a 1819. Os principais investidores foram bancos comerciais internacionais, em sua maioria britânicos ou anglo-holandeses como os Baring Brothers e a Hope and Company. Essas empresas, herdeiras de empreendedores que enriqueceram com o financiamento de guerras europeias setecentistas e com o comércio transatlântico de escravos, especializaram-se em duas áreas. Por trás delas estava o Bank of England, uma parceria público-privada que, como bancos centrais modernos, atuava como emprestador em última instância durante crises financeiras. Os grandes bancos comerciais surpreendentemente eram católicos, baseados em Londres, mas à disposição para vender títulos até mesmo de poderes inimigos. Eles financiaram a compra da Louisiana pelos EUA em 1804, negociaram títulos franceses durante as guerras napoleônicas e compraram dívidas do governo dos EUA enquanto Andrew Jackson se preparava para defender Nova Orleans de um ataque britânico entre 1814 e $1815 .^{15}$

Quando os EUA adquiriram o território da Louisiana, pouco após a vitória dos haitianos sobre o império napoleônico que pretendia reescravizá-los, um imenso continente repentinamente se abriu para aventuras empresariais. 0 comércio a partir do Kentucky e do Tennessee, anteriormente bloqueado pela desconfiança francesa e espanhola do expansionismo estadunidense, finalmente se tornou possivel, ainda que estivesse apenas em seu começo. Para aqueles que testemunharam o rápido crescimento da escravidão no interior da Carolina do Sul e da Geórgia, cujo sucesso se refletia no envio crescente de algodão via Savannah e Charleston, o baixo Vale do Mississippi parecia ser a próxima fronteira de expansão. Bancos comerciais enviavam agentes como Vincent Nolte à Nova Orleans enquanto empresas tentavam lucrar rapidamente com o controle do comércio na foz do Mississippi. Esse comportamento monopolista, no entanto, atraiu competidores com o mesmo objetivo. Alguns eram agentes de firmas maiores, como Nolte, que abandonou sua própria operação e mais de uma vez tentou dominar todo o mercado de algodão. Juntos, e em combinação com as ações do governo dos EUA, que travou guerras pelo controle do Sudoeste e criou seu próprio banco nacional em 1816 para auxiliar o financiamento da fronteira, eles criaram um mercado. ${ }^{16}$ 
17

DEYLE, Steven. Carry Me Back: The Domestic Slave Trade in American Life. New York: Oxford University Press, 2005; JOHNSON, Walter L. Soul By Soul: Life Inside the Antebellum Slave Market. Cambridge: Harvard University Press, 1999.

18

BRUCHEY, Stuart. Cotton and the Growth of the American Economy, 1790-1860. New York: Harcourt, Brace \& World, 1967. p.7.
Não foi apenas um mercado, porém, que foi criado. A partir de 1804, a importância do algodão aumentou rapidamente e atingiu 50\% ou mais do valor de todas as exportações dos EUA em quase todos os anos anteriores à Guerra Civil. 0 produto era a principal base de todas as negociações internacionais envolvendo a importação dos manufaturados britânicos. Os padrões e ciclos do algodão, crédito e outras mercadorias passariam por crises avassaladoras e seriam reconstruídos continuamente. Em cada versão, o ciclo de trocas entre, de um lado, bens e crédito internacionais e, de outro, algodão produzido na fronteira escravista, prosseguia sendo o motor que movia a economia dos EUA. Afinal, o algodão não era responsável apenas pelos ganhos, atividades e saneamento de dividas comerciais de curto prazo. 0 enorme mercado mundial do produto crescia tão rapidamente - com escravistas norte-americanos sendo capazes de extrair de suas pessoas escravizadas não apenas mais algodão, mas um material de melhor qualidade em comparação ao produzido por camponeses livres em outras partes do mundo - que a fronteira do Sudoeste aparecia como o lugar ideal para se colocar dinheiro. Assim, pessoas de fora olhavam com bons olhos para investimentos na capacidade expansionista da produção de algodão.

Esse dinheiro começou a chegar no Sudoeste de diversas maneiras, especialmente após 1815, quando a paz entre Grã-Bretanha, França e os Estados Unidos finalmente permitiu que um comércio irrestrito circulasse o Atlântico. Em Nova Orleans, bancos comerciais adiantavam dinheiro para comerciantes, então autônomos, como Vincent Nolte. Eles, por sua vez, começaram a negociar com vários outros empresários, homens que combinavam a função de corretores de algodão, importadores, credores de produtores de algodão (sendo eles mesmos fazendeiros, como William Kenner de Nova Orleans) e comerciantes de escravos. Com o fim do tráfico de escravos africanos em 1807, os novos campos de trabalho do vale do Mississippi teriam que ser abastecidos de alguma forma. Empresários acionaram suas redes de contatos comerciais, utilizando primos e amigos para a compra de pessoas em Chesapeake e transportando-as, com outros produtos comerciais, em grupos de cinco, seis, dez e doze para Nova Orleans. As pessoas nas fazendas de Chesapeake eram compradas pelos "homens da Geórgia", pequenos comerciantes que ascendiam economicamente através da compra e venda de pessoas. Eles acorrentavam os cativos em um coffle - uma série de correntes interligadas que permitia que dúzias de homens caminhassem juntos sem resistir - e os faziam marchar até o interior da Carolina/Georgia para serem vendidos em novos empreendimentos algodoeiros. Empresários de Nova Orleans passaram então a vender pessoas da Virginia e de Maryland da mesma forma que negociavam títulos de terras, faturas de algodão, empréstimos e dividas. Eles rapidamente criaram um conjunto de instituições e padrões de comércio de seres humanos que resultou no surgimento de expectativas acerca do que constituía a "mão" ideal. Um novo mercado surgia para uma mercadoria específica. ${ }^{17}$

Não havia, entretanto, escravos suficientes para satisfazer todas as expectativas e demandas do mercado mundial de algodão (entre 1815 e 1819 o algodão dos EUA foi responsável por aproximadamente $50-60 \%$ das vendas mundiais, enquanto, após 1825, em mercados muito maiores, o mesmo produto corresponderia regularmente a $80 \%$ do total). ${ }^{18} \mathrm{Ha}-$ via duas opções. A primeira era aumentar o volume de algodão que cada "mão" podia colher nos campos de trabalho escravo. As técnicas de extração anteriormente descritas, o pushing system e a whipping machine, 
desenvolvidas na primeira fronteira do algodão na Carolina do Sul, espaIharam-se rapidamente por todo o Sudoeste nesse período, do Alabama à Louisiana. As cotas subiram, grosso modo, de cinquenta libras por dia para mais de cem. Essas foram as novidades tecnológicas cruciais introduzidas na produção de algodão durante o primeiro episódio da história financeira da Segunda Escravidão. Mesmo com a disseminação dessas inovações pelas novas áreas do Sudoeste, deixando os troncos lisos após as colheitas e os corpos massacrados, as mãos ainda não tinham colhido o suficiente para saciar a demanda do mercado em Nova Orleans.

Se, por um lado, ainda não existia algodão ou trabalho suficientes, por outro havia terra, coisa que os investidores rapidamente perceberam. Andrew Jackson e sua milícia do Tennessee derrotaram os Creeks na bataIha de Horseshow Bend em 1814 e os forçaram a entregarem praticamente todo o Alabama e a região oeste da Geórgia para os brancos. Essas terras eram um fator esperado na produção do algodão, por isso muitos queriam garantir o acesso a elas antes mesmo de poderem transformá-las em campos cultiváveis. Entre 1815 e 1819, o governo federal fez um levantamento e vendeu a maior parte dos quase dez milhões de hectares que compunham as duas áreas. 0 mesmo governo fez empréstimos a longuíssimo prazo para os compradores. Além disso, os "republicanos" jeffersonianos que controlavam o governo dos EUA abandonaram a recente oposição a um banco central e prepararam a criação do Second Bank [Segundo Banco] dos EUA em 1816. Essa instituição deveria regular os incontáveis bancos que foram abertos nos diversos estados, coisa que não fez durante os primeiros quatro ou cinco anos de sua existência. Ao contrário, ela permitiu que esses bancos fabricassem cédulas de dinheiro e as emprestassem livremente aos especuladores de terras, enquanto os próprios burocratas da instituição roubavam dinheiro de seus cofres para ser usado em suas empreitadas especulativas particulares.

Empréstimos para a compra de terras se tornaram o principal instrumento de crédito, a inovação que atraiu investimentos e transformou a paisagem financeira do Sudoeste em fins dos anos 1810. Tomados pela "febre do Alabama", milhares de migrantes abandonaram seus antigos estados escravistas e se deslocaram para o Sudoeste entre 1815 e 1819. Eles também fizeram novos empréstimos e hipotecaram os terrenos que estavam prestes a comprar, recebendo as cédulas recém-impressas pelos bancos e repassando-as aos vendedores de terras. Os preços dessas propriedades continuaram a subir, potencializados pelos olhares céticos que a moeda inflacionada despertara. Compradores adquiriam mais acres sob a perspectiva de que, mesmo que não conseguissem pagar pelos seus empréstimos, sempre poderiam vender suas terras para algum tolo da vez. 0 resultado foi o surgimento de uma bolha especulativa. Conforme aumentavam os preços das terras, bancos locais e até mesmo o B.U.S. [Banco dos Estados Unidos] continuavam a fabricar dinheiro. As contradições acumularam: empreendedores fronteiriços se endividaram, o dinheiro que eles recebiam se desvalorizara e os bancos foram esvaziados por fraudes. Quando os boatos acerca de diretores utilizando e fraudando os fundos de seus próprios bancos se espalharam, a diretoria do B.U.S. cortou os empréstimos e passou a cobrar os devedores. Logo a bolha estourou. Subitamente, credores por todo o Sudoeste e, pouco depois, ao redor de todo o mundo anglo-atlântico passaram a cobrar devedores para que também pudessem sanar suas dividas com o B.U.S. Todos eram devedores, e todo o dinheiro circulante 
19

DUPRE, Daniel. Transforming the Cotton Frontier: Madison County, Alabama. Baton Rouge: Louisiana State University Press, 1997; CATERALL, Ralph. The Second Bank of the United States. Chicago: University of Chicago Press, 1902. p.21-92.

20

KINDLEBERGER, Charles. Manias, Panics, and Crashes: A History of Financial Crises. New York: Basic Books, 1978. que possuiam vinha de bancos cujas práticas corruptas começavam a ver a luz do dia. Incapazes de trocarem suas notas bancárias por outras de maior aceitação, esses bancos fecharam suas portas. Todo o dinheiro que haviam fabricado passou a valer nada mais do que a matéria prima gasta em sua produção. Esse produto era, evidentemente, algodão. ${ }^{19}$

0 Pânico de 1819, como ficou conhecido, se encaixa em cada um dos três elementos da bolha de crédito clássica, conforme caracterizada pelo historiador econômico Charles Kindleberger. Com o desaparecimento das regulações após 1815, empreendedores criaram novos instrumentos de crédito. A combinação entre mais crédito disponivel (e subitamente desregulado) e as inovações tecnológicas que transformaram a economia foram o suficiente para convencer milhões de agentes econômicos de que a história não se repetiria. Todos procuraram mais crédito, que se expandiu, e terras, que encareceram. Quando a bolha finalmente estourou e os preços caíram, essas pessoas se encontraram incrivelmente endividadas. 0 dinheiro que carregavam não tinha valor e a venda das terras que haviam comprado especulativamente pouco ajudaria, já que seus preços caíam rapidamente enquanto todos tentavam vendê-las. ${ }^{20}$

Bolhas de crédito clássicas como a famosa tulipomania holandesa de 1637 foram, de modo geral, muito menores. A bolha em questão, no entanto, emergiu da rápida expansão da Segunda Escravidão, que produzia uma matéria prima fundamental para a indústria e envolvia centenas de milhares de agentes econômicos livres. 0 ecossistema financeiro que gerou a bolha e sua explosão era formado por tipos próprios de instituições, atores e mercados. Talvez a ideia de "ecossistema" dê muita ênfase à estabilidade quando, na realidade, as forças que moldaram o período entre 1804 e 1820 foram inovações radicais que produziram dinamismo. Padrões que apareceriam posteriormente já estavam presentes. Por exemplo, além das relações entre investidores e empresários, inovações organizacionais foram centrais. Igualmente significativos foram os novos instrumentos de crédito e as inovações no tráfico interno de escravos. Modificações na esfera produtiva, especialmente na produção de algodão bruto, influenciaram as dinâmicas e relações típicas da era financeira. Todos esses fatores se combinaram no processo que deslocou 125.000 pessoas escravizadas para os estados do Sudoeste, derrubou milhares de árvores e as substituiu por uma monocultura, aumentou o número de fardos de algodão exportados pelos EUA, criou e destruiu fortunas e estabeleceu expectativas (de que governos e bancos garantiriam o rápido crescimento econômico e o aumento das oportunidades tanto para migrantes escravistas quanto para investidores) e padrões culturais (o leilão de escravos como ponto de encontro de diversas forças econômicas e desejos pessoais).

\section{Era II}

Durante os primeiros anos da década de 1820 , com os negócios estagnados como um motor sem óleo, a fronteira do algodão pouco expandiu. Logo que a maré de desastres financeiros recuou, novas configurações, novas parcerias comerciais e novos relacionamentos entre crédito e débito, produção e consumo, vieram à tona. Uma vez mais os processos de inovação que configuraram o novo mundo financeiro iriam destruir suas próprias estruturas. Essa nova era durou de 1819 a 1833. No lado oeste do Atlântico ela foi dominada pelo Banco dos Estados Unidos. 0 B.U.S., completamente desregulado antes de 1819, tornou-se efetivamente um banco central sob 
HAMMOND, Bray. Banks and Politics in America: From the Revolution to the Civil War. Princeton: Princeton University Press, 1957; KILBOURNE, Richard H. Slave Agriculture and Financial Markets in Antebellum America: The Bank of the United States in Mississippi, 1831-1852. London Pickering \& Chatto, 2006.
DOUGLASS, Frederick. My Bondage and My Freedom. New York: Miller, Orton \& Mulligan, 1855. p.448. a liderança do aristocrata e polímata da Pensilvânia Nicholas Biddle. Ele impediu que bancos menores fizessem empréstimos além de sua capacidade. Nos anos 1824-1825, quando boatos combinados à superprodução transformaram a súbita falta de algodão em uma queda nos preços do produto, o banco de Biddle evitou a crise nos EUA ao atuar como emprestador em última instância. Os bancos permaneceram abertos e as pessoas não perderam suas economias ou foram à falência. A Grã-Bretanha, na verdade, ficou muito pior. $^{21}$

0 B.U.S. também emprestou quantias significativas ao longo da década de 1820, estimulando a economia e permitindo que tanto fazendeiros empreendedores quanto agricultores menores saíssem do buraco de 1819. Ao vender dívidas e ações dos EUA fora do país, o B.U.S. conectou investidores europeus aos comerciantes, fazendeiros e outros norte-americanos, já que a economia financiada pelo algodão prometia grandes retornos se tivesse sua implosão impedida. 0 banco de Biddle também foi fundamental para o surgimento de um grupo de empresas inovadoras e especializadas no comércio de escravos. Essas firmas disciplinaram tanto o mercado fornecedor de escravos do Sudeste quanto sua contrapartida consumidora do Sudoeste. Competindo entre si, elas utilizaram técnicas de transporte mais eficientes. Prisões especializadas para manter indivíduos adquiridos foram construídas e um fluxo constante de pessoas escravizadas foi direcionado aos novos centros comerciais dos estados consumidores, Nova Orleans e Natchez. Firmas surgiram e desapareceram conforme suas lucrativas inovações eram rapidamente adotadas por competidores. A empresa Woolfolk de Austin oferecia pagamentos em dinheiro, hierarquizando indivíduos de acordo com a sua proximidade da condição ideal da mercadoria "mão". Por exemplo, praticamente todos os 20.000 homens e mulheres enviados à Nova Orleans durante esse periodo tinham entre 14 e 23 anos de idade. Eles também eram aparentemente maiores do que a média dos escravos de sua idade e gênero, e é possível demonstrar que cada centímetro adicional de altura possivelmente resultava em um lucro suplementar de aproximadamente dez dólares nos pontos de venda dos estados algodoeiros.

As práticas organizacionais desses comerciantes também eram distintas das utilizadas pelos "homens da Geórgia" e outros empresários de décadas anteriores. Frederick Douglass, uma criança na costa de Maryland nos anos 1820, recordava-se de ver folhetos anunciando a presença de um comprador de Woolfolk em um distrito próximo.22 0 comprador transformava suas aquisições em um negócio regular. Ele não era um vendedor de ocasião, que aparecia em alguma data específica ou no primeiro dia do ano, quando tradicionalmente se dava o aluguel e a venda de escravos no Sul setecentista. Durante o século XIX, à medida que as práticas comerciais e a separação entre casa e trabalho remodelavam as culturas capitalistas do Sul, o comprador de escravos passou a ter um escritório. Ele comprava nos dias úteis, não mais em feriados.

Depois de 1828, uma enorme firma ocupou o lugar de ponta da companhia Woolfolk. A parceria entre Isaac Franklin do Tennessee, R.C. Ballard da Virginia e John Armfield do Distrito de Columbia adotou todas as inovações da Woolfolk - propaganda, compras à vista no atacado de todos que se aproximassem da altura e idade ideais da "mão", e o estabelecimento de prisões e outros "postos" no Sudeste e no Sudoeste, de forma que a compra e a venda pudessem continuar quase que continuamente ao longo de diversas localidades. Eles compraram seus próprios navios e os 
23

GUDMESTAD, Robert. Op. Cit.

24

BAPTIST, Edward E. 'Cuffy', 'Fancy Maids', and 'One-Eyed Men': Rape, Commodification, and the Domestic Slave Trade in the U.S. American Historical Review, v.106, n.5, p.1619-1650, 2001. prepararam de modo semelhante às embarcações do tráfico transatlântico de escravos, despachando-os para Nova Orleans regularmente. Quando, em Richmond, Ballard não conseguiu comprar escravos suficientes para encher o brigue Isaac Franklin, ele não esperou e alugou espaço para a "carga" de outros comerciantes menores, enviando a embarcação para Franklin em Nova Orleans. ${ }^{23}$

0 sucesso de Franklin, Ballard e Armfield - em torno de 1832 eles enviavam mais de duas mil pessoas por ano para Nova Orleans e Natchez era, acima de tudo, produto de duas outras inovações. A primeira estava intimamente ligada ao B.U.S. e outros bancos, que, no ambiente altamente regulado de fins dos anos 1820 e princípios dos 1830, eram criações daquele. Franklin e Ballard movimentaram centenas de milhares de dólares na forma de crédito comercial durante aqueles anos. Seu comportamento consistente e confiável, bem como as negociações em larga escala, permitiu que tivessem acesso a esse dinheiro em bons termos. Eles também se beneficiaram do fato de que Nicholas Biddle redirecionou o foco dos investimentos do B.U.S. para o Mississippi e Louisiana após 1828 (Biddle reconhecia a importância fundamental da expansão do algodão para 0 crescimento da economia dos EUA e buscava o apoio político para sua instituição no Sudoeste). As relações estreitas de Franklin, Ballard e Armfield com o setor bancário os deixaram com uma vantagem significativa. Eles podiam simplesmente comprar mais escravos e em melhores condições, o que levou os Woolfolks a se retirarem de seus principais territórios no interior de Baltimore em princípios dos anos 1830.

A outra inovação da imensa firma de Franklin \& cia foi a criação, consciente ou inconscientemente, de um ambiente de oposição ao crescente culto evangélico à domesticidade. Como o conjunto de hábitos que viria a ser denominado de "vitorianos" estava associado, na visão de muitos, ao estabelecimento de normas femininas, a atmosfera de rebelião criada era atraente para os homens compradores da maior parte dos escravos. A firma de Franklin identificava e vendia mulheres específicas como "fantasias" brinquedos sexuais, geralmente jovens e "brancas", isto é, de óbvia ascendência afro-europeia. Esse processo era objeto de longas discussões entre os membros da firma, claramente maravilhados com o poder de mercantilizar a sexualidade dessas mulheres. Eles também faziam piada sobre serem forçados a lidar com elas, conforme se deslocavam de um lado a outro no Sul. Esses homens se viam como outsiders - se apelidando de "piratas" ou "caolhos", este uma gíria para pênis - o que os estimulava a um comportamento financeiro agressivo e fora da lei (não é incomum que grupos de homens no centro de inovações empresariais se vejam como um bando de foras da lei que combatem as convenções tradicionais da sociedade, sentindo-se no direito de pegarem o que quiserem e quando quiserem de seus clientes, mulheres e empregadores. Se você não acredita, pergunte a qualquer funcionário abaixo dos 30 anos na Goldman Sachs em Manhattan se ele trapaceou algum cliente ou se teve comportamento sexual de risco com alguma mulher embriagada na semana passada). ${ }^{24}$

A mercantilização sexual - um aspecto constante da escravidão foi intensificada, em parte porque ia de encontro às nascentes normas burguesas a respeito do sexo fora do casamento. A possibilidade desse tipo de rebelião demonstrava a relação entre escravização e sexualidade forçada, com a implicação de que escravistas pensavam ativamente a respeito dessa conexão, o que, por sua vez, estimulava dinâmicas que 
pesquisadores de economia comportamental identificam em diferentes contextos. Em testes de laboratório associando mercadorias à sexualidade, homens que percebem essa conexão tendem a se arriscar mais economicamente, mesmo que esses riscos não estejam diretamente ligados ao acesso às mercadorias em questão.

Estava aqui, no entanto, o problema. A complexidade e crescente efetividade do novo tráfico doméstico de escravos espalhou seus tentáculos pelo Sudoeste. 0 desejo por mais riscos aumentou, mas diversos controles restringiram os pretensos empreendedores de aproveitarem oportunidades que eles crescentemente enxergavam como suas. Nesse grupo estavam os traficantes de escravos, fazendeiros de algodão, comerciantes, banqueiros e a multidão de brancos que sonhavam em se juntar a essas categorias. Eles queriam crédito para poder comprar mais escravos. Na realidade, além do papel que o tráfico doméstico de escravos teve em estimular os desejos de homens brancos em se arriscarem, outras inovações também aguçavam o apetite pela expansão de seus investimentos. Escravistas, ou mesmo feitores que quisessem iniciar operações por conta própria se conseguissem crédito, observavam que as técnicas da whipping-machine para a maior produtividade se refletiam no volume crescente de algodão colhido por cada escravo. Um motivo foi a introdução de outros tipos de algodão nos anos 1820, que pode, por um lado, ter tornado o algodão mais "fácil" de se colher, mas que, por outro, certamente aumentou a quantidade de fibras de algodão em cada hectare de plantas prontas para a colheita. Por conta da crescente procura e das cápsulas de algodão mais grossas que cresciam em cada pé, a década de 1820 foi o período em que um número cada vez maior de escravos teve que aprender a usar as duas mãos contínua e independentemente uma da outra para satisfazer as demandas. Era um trabalho complicado. Imagine aprender a tocar piano - uma tarefa que exige que as mãos atuem independentemente - e passar por esse aprendizado não como uma criança, mas como um jovem adulto. Agora imagine fazer isso catorze horas por dia durante os cinco meses de colheita do algodão. Era isso que pessoas escravizadas eram forçadas a fazer com a ajuda das tecnologias de medição e tortura.

0 número de fardos de algodão aumentava e pilhas cada vez mais altas ficavam à espera dos novos barcos a vapor que aproximavam cada vez mais os produtores de algodão dos corretores de Nova Orleans ou Mobile. Escravistas imaginavam o quão mais altos poderiam ficar seus montes de algodão, se eles conseguissem mais empréstimos para comprar escravos, cada vez mais fáceis de se obter devido às atividades dos grandes comerciantes e seus competidores. 0 B.U.S., no entanto, manteve instituições financeiras locais, como o Banco de Natchez do estado do Mississippi, sob rígido controle. Ainda que esses bancos e o B.U.S. aumentassem a quantidade de empréstimos em torno de 1830, eles eram direcionados, antes de tudo - ou assim acreditavam seus críticos - para os círculos de parentes e amigos dos bancos locais. Quem não fazia parte desses círculos encontrava maior dificuldade para conseguir empréstimos. Essas pessoas e seus aliados políticos - junto com políticos do Sudoeste comprometidos com o "anti-banquismo" - começaram a reclamar agressivamente da dominação do B.U.S. As críticas encontraram uma audiência pronta: o presidente Andrew Jackson, que suspeitava que o B.U.S. havia lutado contra sua eleição, e os homens brancos menos ricos, que podiam ser trabalhadores urbanos do Norte ou pequenos proprietários sulistas, mas que conjunta- 
WILENTZ, Sean. The Rise of American Democracy: Jefferson to Lincoln. New York: Norton, 2005. mente culpavam o B.U.S. pelo Pânico de 1819 e a contração econômica que se seguiu. "0 Banco foi salvo, mas as pessoas perderam", disse o ideólogo anti-banco Thomas Hart Benton, senador do Missouri, em um exemplo do apelo que tais críticas tinham para aqueles que se opunham às centralizações do poder econômico.

Em 1832, o Banco requisitou uma extensão de sua licença, cujo vencimento se daria em 1836. 0 Congresso aprovou a nova licença, mas o presidente Andrew Jackson, em uma ação inédita, a vetou. Com o argumento de que a posição oficial do Banco resultava em um apoio desproporcional do governo, permitindo que seus ricos acionistas lucrassem com um monopólio anti-republicano, ele denunciou o B.U.S. e apostou as fichas de sua reeleição na crença de que o eleitorado apoiaria sua ação (em sua "Mensagem de Veto", Jackson também denunciou o B.U.S. por escoar as riquezas do Oeste e do Sul, onde a maior parte dos devedores se encontravam, para o Norte e outros paises, onde estavam a maior parte dos acionistas do Banco. Claro que outra forma de ler esses dados é reconhecer que a distribuição de acionistas e empréstimos revela que o B.U.S. era uma maneira de europeus e nortistas investirem na expansão do algodão escravista do Sudoeste. Empresários do Sudoeste podiam igualmente utilizar o capital daquelas regiões para comprar terras, escravos e suprimentos e assim financiar seus empreendimentos em permanente expansão). ${ }^{25}$

Jackson foi reeleito e teve, então, poder para causar a crise que destruiria a segunda era da história financeira da Segunda Escravidão. Dessa crise surgiria a terceira era. Uma coalizão de empreendedores e pequenos proprietários do Sudoeste com trabalhadores e empresários ascendentes do Norte apoiaram Jackson. Esse grupo formaria o núcleo do Partido Democrata. A batalha em torno das finanças concebeu os dois partidos da era anterior à Guerra Civil. Os oponentes de Jackson - as elites estabelecidas que o odiavam por conta do veto ao Banco e o os reformistas religiosos que o detestavam por continuar expulsando os índios do Sudoeste - se tornaram os Whigs. Jackson aumentou a crise ao remover os depósitos governamentais do B.U.S. em 1833 e transferi-los para um conjunto de outras instituições comandadas por diretorias politicamente aliadas. A reação de Biddle foi cobrar os milhões de dólares em empréstimos do B.U.S., levando o país a uma recessão que durou meses entre fins de 1833 e princípios do ano seguinte. Delegações de empresários visitaram Jackson e imploraram que ele voltasse atrás, enquanto políticos do Sudoeste conectados ao B.U.S., como o senador do Mississippi George Poindexter, ameaçaram a vida política, e até mesmo pessoal, do presidente. Jackson, no entanto, tinha enorme força e acabou com os desejos de seus oponentes. Em pouco tempo, o então desestabilizado B.U.S. procurava alguma legislatura estadual que providenciasse uma licença para que o banco funcionasse como uma instituição privada, o governo federal depositava os ganhos de impostos e vendas de terras com sucesso nos "pet" banks e um novo boom se iniciava.

\section{Era III}

A destruição do B.U.S. acabou com todo o controle regulatório exercido sobre as finanças da expansão da escravidão. Da gaiola aberta escaparam todo tipo de bestas, que se proliferavam rapidamente e transformavam tanto as ecologias financeiras quanto biológicas do Sudeste dos EUA. De 1833 a 1837, escravistas empreendedores, financistas, comerciantes, traficantes de escravos e especuladores saíram de controle. Eles mais do que 
BAPTIST, Edward E. Toxic Debt, Liar Loans, Collateralized and Securitized Human Beings, and the Panic of 1837. In: ZAKIM, Michael; KORNBLITH, Gary J. (org.). Capitalism Takes Command: The Social Transformation of Nineteenth-Century America. Chicago: The University of Chicago Press, 2012. p.69-92. dobraram todo o investimento que o B.U.S. já direcionava para as fronteiras expansionistas da escravidão. Com esse dinheiro eles iriam importar quase meio milhão de pessoas escravizadas para o Sudoeste, fazendo-as passar por tormentos inimagináveis enquanto eram arrancadas de tudo que conheciam, mercantilizadas e forçadas a aprender a colher algodão sob a constante ameaça do chicote. Seus preços em Nova Orleans subiram mais do que o dobro: homens jovens que custavam 650 dólares eram vendidos por mais de 1300. A demanda continuou a crescer, aumentando o número de mãos e de fardos de algodão. Do veto de Andrew Jackson à renovação da licença do B.U.S. até 1837, a produção de algodão no Sul dobrou.

Após 1832, empreendedores-escravistas e intermediários demonstraram estar preparados para a oportunidade oferecida pela eliminação dos limites aos empréstimos impostos pelo B.U.S. Na verdade, eles vinham testando versões preliminares de novos instrumentos de crédito e formas de organização desde 1827. Foi então que escravistas da Louisiana e representantes dos Baring Brothers, o grande banco comercial de Londres, criaram, com o auxílio da legislatura da Louisiana, a "Associação Consolidada de Fazendeiros da Louisiana" (C.A.P.L. - Consolidated Association of the Planters of Louisiana). A instituição era uma espécie de banco, construida para direcionar o dinheiro de investidores para os fazendeiros, enquanto outros dois grupos - os contribuintes da Louisiana e os investidores dos mercados financeiros mundiais - arcavam com o risco financeiro. A escritura elaborada pelos escravistas e empresários Hughes Lavergne, J.B. Moussier e Edmund Forstall da Louisiana de um lado, e Thomas Baring de outro, foi construída da seguinte forma. Mutuários em potencial hipotecariam seus escravos e terras em troca de ações hipotecadas nos bancos com até dois terços do valor de suas propriedades. Donos de ações teriam direito a empréstimos baseados no valor contábil de suas posses. 0 dinheiro para os empréstimos viria dos títulos que a C.A.P.L. vendesse nos mercados financeiros mundiais com a ajuda dos Baring Brothers, experientes na venda de valores mobiliários para estados-nação (o banco seguraria as notas de libras esterlinas que eram usadas na compra de debêntures para servirem como uma pequena reserva de garantia de suas próprias notas, que eram distribuídas não apenas para hipotecar mutuários, mas como crédito de curto prazo para comerciantes negociadores de algodão e outras mercadorias). Com a intenção de convencer os compradores de debêntures de que os valores mobiliários da C.A.P.L. eram investimentos de baixo-risco, os criadores do banco utilizaram suas inúmeras conexões políticas para persuadir a legislatura do estado da Louisiana a garanti-los com a "fé e crédito do estado da Louisiana". 26

Os valores mobiliários da C.A.P.L. foram colocados à venda em 18291830 e rapidamente comprados em Londres e Amsterdã. Um milhão de dólares foi o valor da primeira emissão de obrigações e outro um milhão viria logo em seguida. Milhares de escravos foram hipotecados para a C.A.P.L., que planejava pagar o capital e juros (geralmente quatro por cento, pagos anualmente) das debêntures com os pagamentos de seus devedores sulistas. Os ganhos gerados pelos escravos hipotecados, portanto, deveriam pagar pelas debêntures. Cada debênture - inicialmente valendo quinhentos dólares, mais tarde mil - tinha seu preço fixado mais ou menos de acordo com o valor de um escravo em Nova Orleans. Se um cativo morresse de malária ou de tétano resultante de um açoitamento, fugisse e se escondesse com sucesso em um navio carregado de algodão com destino a Liverpool 
27

MCGRANE, Reginald. Foreign Bondholders and American State Debts. New York: The Macmillan Company, 1935. p.228-229; R.T. Hoskins to R.T. Brownrigg, 19 de dezembro de 1835, Fol. 3, Brownrigg Papers, Southern Historical Collection, University of North Carolina-Chapel Hill; MILES, Edwin A. Jacksonian Democracy in Mississippi. Chapel Hill: 1960. p.140-141; ROEDER, Robert E. New Orleans Merchants, 1790-1837. Tese de Doutorado. Harvard University, 1959, p.334. ou fosse assassinado pela pistola de um feitor, nenhum investidor teria que arcar com as perdas. Aquele escravo e sua hipoteca foram "securitizados" - tanto os ganhos que geravam quanto os riscos de sua perda foram divididos em porções infinitesimais idênticas para cada uma das duas mil debêntures. De certo modo, portanto, a debênture da C.A.P.L. era um escravo completamente mercantilizado. Logo, uma pessoa poderia possuir uma debênture e conseguir oito por cento de seu investimento todo ano sem se preocupar se o escravo comprado alcançava os galhos mais altos dos algodoeiros, se estava doente demais para atingir sua cota, se era rebelde demais para ser mantido em um campo de trabalho escravo ou mesmo se era, na verdade, um homem livre (como Northup). Da perspectiva do investidor de 1829, estivesse ele em um salão em Mayfair ou em um escritório em Amsterdã, extrair os ganhos era um problema do escravista, enquanto os juros de quatro por cento era o preço pago pelo uso de seu capital.

A economia financeira da Segunda Escravidão, dando suporte à expansão regular entre 1819 e 1833, estava prestes a se tornar mais dinâmica. Ávidos por um novo boom, empreendedores-escravistas se ressentiam das regulações impostas pelo B.U.S. quase com a mesma intensidade com que odiavam o tratamento especial dado pelo Banco a alguns grupos (quando não eram, evidentemente, parte deles): membros de facções de bancos locais, grandes traficantes de escravos e acionistas obscuros do B.U.S. Enquanto Jackson destruia Biddle e toda autoridade regulatória desaparecia, legislaturas estaduais licenciavam uma série de instituições baseadas no modelo da C.A.P.L. Cada uma delas hipotecou escravos e fez empréstimos aos empreendedores escravistas, financiando seu capital inicial com a venda de debêntures. 0 Union Bank da Louisiana vinha logo atrás do C.A.P.L. Ele havia levantado capital com a venda de sete milhões de dólares em debêntures através dos Barings. A Louisiana então licenciou o Citizens Bank, com a emissão de obrigações no valor de doze milhões de dólares, seguido de inúmeras instituições menores financiadas da mesma maneira. Em torno de 1836, a Louisiana havia expandido o número de seus bancos de quatro para dezesseis, e de nove milhões de dólares para quarenta e seis em capital. Outros estados do Sudoeste não ficavam muito atrás. A Flórida (na época apenas um território e não um estado) autorizou a formação de três bancos, com um total de quatro milhões de dólares em debêntures. 0 Tennessee, Arkansas, Mississippi e Alabama utilizaram técnicas semelhantes. Em 1832, o total de empréstimos bancários disponível para mutuários no Sudoeste era de menos de quarenta milhões de dólares, incluindo os trinta milhões emprestados pelo B.U.S. Em torno de 1837, mesmo com a saída do B.U.S., os empréstimos bancários do Sudoeste chegaram a mais de oitenta milhões de dólares - um terço do total nacional, uma quantia maior do que o de qualquer outra região. Legislaturas do Sudoeste permitiram a circulação de muito mais capital bancário durante a década de 1830 do que o aplicado pelo B.U.S. na economia dos EUA como um todo anteriormente. ${ }^{27}$

Aqueles que faziam empréstimos baseados em seus escravos podiam evidentemente usar o dinheiro para comprar mais escravos. 0 que permitia que fizessem mais empréstimos. Conforme a demanda por escravos aumentou, o tráfico de escravos também cresceu, mas os grandes traficantes não conseguiram acompanhar. 0 preço dos escravos aumentou e dezenas de novos comerciantes entraram no negócio. As pessoas continuaram a fazer empréstimos. Crédito era fácil e escravos rendiam, alguns diziam, vinte ou 
trinta por cento a mais do que seu preço inicial após um ano de trabalho devido aos altos preços do algodão. Além disso, mesmo que o preço do algodão caísse ou uma seca resultasse em uma diminuição no volume coIhido, era sempre possivel vender escravos. Parecia que seus preços continuariam a subir indefinidamente. Por que não fazer mais empréstimos? Por que não criar escravos que não existiam para serem usados como garantia e então pedir para que um primo que fosse parte da diretoria de um banco assinasse a avaliação? Por que não hipotecar escravos que já estavam hipotecados para outro banco? Finalmente, por que não subscrever um empréstimo para um irmão, um primo ou um amigo? Afinal, eles fizeram o mesmo por você e essa cobertura mútua fazia com que tudo parecesse mais seguro. Não seria uma falência que derrubaria uma vizinhança, um parceiro comercial ou um banco. Os investidores, enquanto isso, juntavam os cupons de suas debêntures enquanto os bancos comerciais vendiam ainda mais valores mobiliários para outros investidores. Em torno de 1836, até mesmo estados não-escravistas procuravam levantar dinheiro com organizações e instrumentos de crédito semelhantes. À medida que aumentava a especulação de terras no vale do Mississippi, um jovem legislador do estado de Illinois chamado Abraham Lincoln ajudava a passar um projeto de lei que financiaria um complexo sistema de melhoras nos canais e rios baseado em debêntures, enquanto Pensilvânia, Indiana e Michigan emitiram valores mobiliários semelhantes.

Consequentemente, um imenso sistema de empréstimos - cuja posse se encontrava fora do Sudoeste em 1836 - foi transformado em um esquema de pirâmide sob o argumento de que os investimentos gerariam ganhos. Parecia uma expectativa razoável. Investimentos geravam algodão e o produto era a alma das novas indústrias. Fábricas expandiam em tamanho e número não apenas em Manchester, na Inglaterra, mas também em Massachusetts e Rhode Island, além de França, Alemanha e Itália. 0 sucesso na utilização de técnicas financeiras e instrumentos de crédito por empresários, bem como o sucesso das novas tecnologias de medição e tortura utilizadas na extração de novas reservas de produtividade no campo, atraíram uma imensa quantidade de capital. Bancos desregulados e mutuários corruptos, então, alavancaram aquele capital significativamente. Tudo dependia da capacidade de pessoas escravizadas em produzirem ganhos que impediriam as dívidas de se tornarem tóxicas. Quanto mais rápido eles colhiam, contudo, mais baixo ficava o preço do algodão. Ainda que a empolgação econômica que emanava dos circuitos de algodão e crédito tenha se refletido no aumento de preços, investimentos, produção, ganhos e consumo em lugares distantes como Nova Inglaterra, Grã-Bretanha, 0 continente europeu e até mesmo a Índia, a capacidade de comprar algodão do mundo não havia exatamente dobrado. Em fins de 1836, o preço do algodão começou a cair.

Os primeiros sinais de alerta eram visiveis no lento declínio dos preços do algodão entre 1835 e 1836. Negociantes, que também dependiam de parceiros comerciais para girar seu capital, enviavam quantidades cada vez maiores de algodão e seus lucros totais permaneciam altos. Entretanto, uma vez mais e em uma escala muito maior, uma bolha especulativa que surgiu em consequência da economia altamente produtiva e eficiente do Sudoeste estava prestes a estourar. Em meados de 1836, o Bank of England, após receber relatórios de um acúmulo de estoques nas fábricas têxteis, passou a cortar os empréstimos para corretores de algodão. Os Barings 
começaram a retirar seus investimentos ativos dos bancos do Sudoeste onde fosse possivel. Em janeiro de 1837, quando uma grande safra de algodão inundou o mercado de pouca demanda de Liverpool, firmas inglesas consumidoras do produto entraram em colapso. Elas não podiam pagar as firmas de Nova Orleans, que, dependentes das vendas em Liverpool, também fracassavam. Em princípios de março, não havia negócios sendo feitos nos setores comerciais de Nova Orleans ou Nova lorque.

Por todo o interior do Sudoeste, em cada fórum distrital, credores cobravam devedores. Mas todos deviam. E ninguém aceitaria as cédulas de dinheiro emitidas pelos bancos do Sudoeste, que eram então nada além de evidências sem valor de como seus empréstimos excediam suas reservas. Escravistas endividados tentaram vender seus escravos, mas eles valiam apenas uma fração de seus antigos preços. Milhares de empresários fugiram para além da fronteira do Texas com seus cativos para evitar os preços de liquidação. Essa era uma solução microeconômica para a crise das dívidas na fronteira da escravidão, mas a devastação da qual esses brancos fugitivos "G.T.T." (G.T.T. = "Gone To Texas" ["Foi Para o Texas"] era o apelido que aparentemente se rabiscava sobre os casos de dividas abandonadas nos tribunais ou nas portas das casas grandes construídas pela metade) tentavam escapar atingiu toda a economia atlântica. Soluções macroeconômicas fizeram pouco mais. Seguindo a filosofia que hoje em dia chamamos de austeridade, o presidente Martin Van Buren se recusou a aumentar os gastos do governo. Nicholas Biddle e outros financistas tentaram reconstruir as redes financeiras da economia atlântica através da transformação dos valores futuros do algodão em uma espécie de moeda, que resultou em uma recuperação parcial em 1838. As "pós-notas" de Biddle e outros logo não podiam mais serem recuperadas, já que a reação de escravistas foi produzir mais algodão e a economia entrou em uma crise ainda mais profunda em 1839. Classes trabalhadoras urbanas ficaram desempregadas em Nova Orleans, Nova lorque, Newcastle e nas novas cidades têxteis do vale do Reno. A devastação das últimas convenceu um jovem estudante de Direito chamado Karl Marx de que o capitalismo crescia através de uma série de crises de superprodução em alternância com booms estimulados por novas tecnologias. Ele apenas errou o centro de causalidade, já que não sabia a respeito da mágica roubada das mãos.

Solomon Northup sabia. Ele viu Patsey nos campos. Ele veio à Louisiana logo após o colapso da Era III das finanças da Segunda Escravidão. Vendas de escravos atingiam niveis inéditos em Nova Orleans e talvez tenha sido justamente isso que esteve por trás de seu sequestro. Ele não custou nada aos negociantes além das drogas usadas para dopá-lo e cada centavo conseguido por ele era lucro. Seus escravizadores o colocaram no campo para gerar o dinheiro necessário para sanar suas dívidas. Representantes de bancos de Nova Orleans à Filadélfia e Nova York varriam os tribunais da Louisiana e Mississippi, tentando recuperar na justiça suas condições de solvência. A única maneira com que fazendeiros individuais poderiam pagar suas dívidas em dinheiro era aumentando os ganhos com algodão. Isso manteve os preços baixos até fins dos anos 1840, quando a demanda mundial finalmente começou a acompanhar a produtividade dos escravos do Sudoeste. Em maior escala, porém, compradores de debêntures começaram a requisitar seus pagamentos enquanto bancos como o Union Bank da Florida não tinham dinheiro ou ativos bancários. Seus processos de encerramento geraram frustração, já que devedores podiam mover escra- 
vos, que, de qualquer forma, não teriam o mesmo valor em tempos de depressão econômica. Os bancos se declararam, então, incapazes de quitarem as debêntures e repassaram o problema aos estados, que, em momentos mais otimistas, apoiaram o sistema.

Privatizar os lucros e socializar os custos: essa era uma técnica antiga e constantemente utilizada com as ferramentas financeiras para aumentar a riqueza e a capacidade produtiva de empresas capitalistas através da extração de dinheiro da população contribuinte mais ampla. Os votantes do Sudoeste, no entanto, criaram uma barreira. Em estado após estado, eles rejeitaram políticos que apoiassem o pagamento das dívidas e votaram a favor de homens que eram eles mesmos devedores. As novas legislaturas repudiaram as debêntures, gerando enorme, ainda que fútil, indignação entre 0 alto escalão das burguesias britânica, holandesa, francesa, alemã e do Norte dos EUA (não foram apenas os burgueses que ficaram revoltados. Nos anos 1930, o principado de Mônaco ainda tentava receber do Mississippi o pagamento por algumas debêntures do Union Bank daquele estado). Todos tiveram, ainda assim, que eventualmente negociar com 0 Sudoeste. A despeito da crescente diversificação, financiada em parte pelos lucros do algodão, todas as instituições financeiras ocidentais estavam de algum modo atreladas à produção, aquisição, transporte, seguro e venda do algodão. 0 rancor entre investidores e intermediários persistia junto com um sentimento mais profundo de desconfiança. Quando emprestassem novamente para empreendedores do Sudoeste, parceiros comerciais exigiriam maior segurança. Mas eles reapareceriam.

\section{Interrupção}

0 leitor deve estar se perguntando: o que aconteceu com a Primeira República que prometi discutir? De modo geral, o que aconteceu com a política? Não foi essa a era, de 1804 aos anos 1840, de democratização dos brancos? Não foi quando surgiu o Segundo Sistema Partidário? Não ocorreram uma série de crises políticas - sobre o Missouri, sobre a Tarifa de Abominações e sobre a constante insistência da Carolina do Sul sobre a nulificação - que resultaram em vários compromissos fundamentais, geralmente tomados como momentos-chave da narrativa política pré-Guerra Civil?

A resposta é que, quando focamos na explicação do maior e mais importante fenômeno da história dos EUA pré-Guerra Civil - a implacável transformação geográfica, demográfica e produtiva causada pela expansão da escravidão - a história de compromissos e formação de partidos se torna praticamente irrelevante. A única exceção, ao menos parcialmente, foi a democratização da política, que, ainda que não tenha alterado significativamente as relações entre Norte e Sul, forneceu à Jackson e seus tenentes políticos em estados como o Mississippi a garantia que ele precisava para poder subverter o controle regulatório do B.U.S. sobre o financiamento da expansão escravista. Esse desenvolvimento evidentemente teve o efeito inverso, presume-se, daquele desejado pelos homens brancos comuns. A mudança levou ao aumento do número de empreendedores que podiam apostar com o apoio do estado, mas quase todos os novos bancos continuavam a excluir a maioria dos eleitores de seus benefícios. Eles não estavam interessados em providenciar empréstimos para brancos pobres, que tentavam ascender à posição de grandes fazendeiros. Deixando de lado, portanto, esse caso irônico de expansão democrática, que implicou dinheiro de graça para as elites a custas de contribuintes e escravizados, interven- 
ções políticas em nenhum momento impediram a expansão da escravidão antes de fins da década de 1840 (escravizadores não queriam adentrar a região norte do território da Louisiana além do Missouri, portanto, o que eles dispensaram no Compromisso do Missouri foi irrelevante até o momento em que se tornou um precedente em potencial para outras aquisições).

Nós deveriamos considerar o período entre a Constituição e a Guerra Civil como a era da Primeira República na história dos EUA. Durante essa época a política nacional e os agentes políticos do Norte (políticos, ativistas, eleitores) eram consciente ou funcionalmente subservientes à expansão da escravidão, ao menos até meados dos anos 1840. A dominação de interesses escravistas sobre a política federal criou um estado cuja função central era estimular a expansão da escravidão. Naquele mundo político, muitos nortistas consideraram seus próprios interesses e concluíram que tinham muito a ganhar ao permitirem tal expansão. Eles atuaram como enzimas eficazes na digestão senhorial do processo político e acabaram com toda a oposição à dominação do famoso "Poder Escravista" sobre a política nacional. Em contrapartida os aliados do Norte foram recompensados, ao menos por um tempo, por terem apoiado a expansão.

Durante sessenta anos nada mudou além da adição de mais eleitores. Duas forças, todavia, racharam as estruturas até então hegemônicas. Por um lado, alguns nortistas resistiram à dominação sulista dos partidos Democrata e Whig e foram capazes de atrair uma minoria de eleitores nortistas em seu favor por meio das consistentes denúncias contra a expansão da escravidão. Por outro, uma minoria de sulistas radicais foram capazes de convencer seus colegas da região a manterem seus respectivos partidos políticos como reféns, sob a condição de que estes afirmassem seu compromisso com uma forma mais extrema de expansionismo escravista, que teria - se levada ao limite de sua lógica calhouniana - tornado a escravidão legal em todas as partes dos EUA. As persistentes estruturas da Primeira Republica finalmente começaram a ruir em um longo período de crise. Sulistas destruíram a estrutura política da Primeira República que Ihes havia sido tão útil.

Muito tempo se passou, no entanto, antes que qualquer coisa mudasse. A história de Solomon Northup, de um homem fugindo da escravidão, nos diz muito a respeito do sucesso da escravidão sulista e demonstra por que sua expansão é o aspecto mais importante da história dos EUA. Quando falamos da história dos Estados Unidos, ocasionalmente discutimos a interrupção causada pela Guerra Civil e as imensas transformações constitucionais que constituíram a emancipação e reconstrução do Sul pós-escravista. Mas geralmente não vemos essa mudança como a criação de um regime constitucional completamente novo. Esse tipo de distinção é deixada para, por exemplo, historiadores franceses, que falam de uma "Primeira República", um "Segundo Império", e assim sucessivamente, chegando a uma "Quinta República" dos dias de hoje. Tais distinções reconhecem a tumultuada instabilidade que tem sido encarada como a principal falha do sistema francês desde o fim do Ancien regime, em contraste com a visão dos estados Anglo-Americanos como modelos de estabilidade.

Quando historiadores geralmente discutem as relações entre os fundadores e a escravidão, bem como a forma como os compromissos constitucionais se deram durante os setenta e poucos anos de história dos EUA, enfatiza-se uma contradição entre a ideologia professada na fundação da república e a realidade da presença perene da escravidão. Com Jefferson e 
gerações de historiadores nacionalistas, nós escrevemos essa história em diferentes modos de tragédia. É, de fato, uma tragédia, mas essas histórias frequentemente exploram as tensões inerentes à condição hipócrita dos brancos com tanto afinco que perdem de vista a panóplia de morte, roubo, separação, orfandade, mutilação, tortura e outras formas de miséria humana que a expansão da escravidão deixou em seu rastro. Para a maioria dos americanos brancos, o fato de que a fundação incorporou a continuação da supremacia branca e a expansão da escravidão não foi vista como uma tragédia. Era uma realidade ambivalente, não uma excrescência, mas sim uma fundação, um compromisso aceitável e até mesmo sagrado que salvou mais do que perdeu. Para outros ela era a condição sine qua non do acúmulo sem fim de riqueza - não um defeito, mas um componente essencial. Se eles observassem com mais atenção, para além dos ganhos que o movimento para oeste da whipping machine Ihes dava como indivíduos, capitalistas sensatos, ainda que amorais, veriam que o sucesso da escravidão foi o que fez com que a Primeira República sobrevivesse.

Desde a fundação dos EUA em 1776, escravistas visando a expansão da escravidão dominaram as decisões políticas nacionais. Tanto na posição de líderes políticos quanto em seus grupos de interesses, eles garantiram, desde os primeiros dias da Confederação, que a República Federal em desenvolvimento depositasse sua autoridade e fundos no projeto de crescimento geográfico da escravidão. Mesmo aqueles que, como Thomas Jefferson e George Mason, lamentavam a influência da escravidão, rapidamente abandonaram a ideia de colocar limites unilaterais na expansão do escravismo em princípios dos anos 1780. Pelo contrário, eles apoiaram propostas que abriram os territórios do oeste para a escravidão e prepararam o terreno para um tráfico interno de escravos. 0 tráfico interestatal, consequentemente, gerou lucros nas regiões com os excedentes de pessoas escravizadas de Chesapeake, um fato enfatizado com certo desgosto pelos delegados da Carolina do Sul na Convenção Constitucional de 1787. Naquele momento o tráfico doméstico ainda estava desorganizado e escasso, mas virginianos faziam previsões cuidadosas em cima das curvas de oferta e demanda: se o tráfico atlântico de escravos fosse fechado como eles desejavam, os empresários da Geórgia e Carolina do Sul, que abriam a fronteira para o algodão no interior de seus estados, não teriam outra opção exceto comprar as crianças excedentes dos antigos distritos produtores de tabaco e grãos.

0 acordo constitucional que estendeu a vida do tráfico atlântico de escravos até pelo menos 1807 foi realizado, em parte, porque a Geórgia e as Carolinas ameaçaram abandonar o projeto nacional se não Ihes fossem dadas duas décadas de fronteiras abertas, para poderem suprir seus novos empreendimentos com escravos africanos pelo menor preço possivel. Alguns protestaram na Convenção, afirmando que o tráfico atlântico de escravos era imoral, como argumentavam os ativistas britânicos Olaudah Equiano e Granville Sharp através de novas técnicas de propaganda e formação de opinião pública. Entretanto, John Rutledge da Carolina do Sul, que logo seria nomeado presidente do Supremo Tribunal Federal, insistiu que "religião e humanidade não tem relação com essa questão... apenas o interesse é o princípio condutor entre nações". Rutledge foi apoiado por Oliver Ellsworth de Connecticut e outros representantes dos distritos litorâneos de Nova Inglaterra, todos dominados por comerciantes. Respondendo a Rutledge e seu companheiro da Carolina do Sul, Charles Pinckney - que 
The Founders' Constitution, Vol.3, p.279-281.
29 FEHRENBACHER, Donald. The Slaveholding Republic: An Account of the U.S. Government's Relations With Slavery. New York: Oxford University Press, 2001; LIGHTNER, David. Slavery and the Commerce Power: How the Struggle Against the Interstate Slave Trade Led to the Civil War. New Haven: Yale University Press, 2006. VAN CLEVE, George W. A Slaveholders' Union: Slavery, Politics and the Constitution in the Early American Republic. Chicago: University of Chicago Press, 2010; ROBINSON, Donald. Slavery in the Structure of American Politics, 1765-1820. New York: Harcourt Brace Jovanovich, 1970. pediu que os "estados carregadores" refletissem a respeito do fato de que seus ganhos eram baseados no transporte de mercadorias produzidas por escravos para os mercados europeus, como anis, arroz e, a partir daquele momento, algodão - , Ellsworth delicadamente requisitou que seus amigos delegados "não se intrometessem". Que deixassem o mercado decidir de onde viriam os escravos, fosse da África ou da Virginia. A Convenção então estendeu a existência do tráfico por pelo menos mais vinte anos. Talvez 200.000 novos africanos escravizados fossem carregados para os EUA em consequência do desejo da Convenção de colocar o interesse em primeiro lugar. Essa não foi, todavia, a única forma com que a Constituição de 1787 infiltrou interesses escravistas e o momento expansionista diretamente na estrutura da nova União. ${ }^{28}$

Nem a lei por si só, nem a linguagem utilizada nos acordos estabelecidos entre as quatro paredes do Independence Hall em meados de 1787, revelam como escravistas expansionistas conseguiram dominar a primeira república americana desde seus primórdios. Talvez o mais importante fosse o mais controverso, que foi o impacto da lei enquanto prática. $E$ não foram quaisquer leis. As mais importantes garantiram que os direitos de propriedade se sobreporiam à liberdade, tanto na forma de direitos naturais quanto nas decisões legislativas das maiorias que representavam os cidadãos. Historiadores do direito têm demonstrado como conflitos entre proprietários e comunidades mais amplas emergiram em debates a respeito do privilégio de capitalistas em infringir os direitos tradicionais aos "comuns", como, por exemplo, na construção de grandes barragens que impedissem as migrações de sável e salmão e, consequentemente, dificultassem o acesso de famílias pobres a alimentos ricos em proteína. Fundamentais para a Primeira República, no entanto, foram as decisões da Suprema Corte dos Estados Unidos, os detalhes que foram incutidos na Constituição e as políticas governamentais que determinaram o princípio de que ninguém poderia limitar futuramente o direito legal de escravistas possuírem pessoas e usá-las como mercadorias. Mais explícita foi a inclusão de uma cláusula de escravos fugitivos na Constituição, imediatamente ativada pela lei de 1793 passada pelo Congresso. Leis federais insistiam que o direito de propriedade de escravistas sobre os corpos de pessoas escravizadas estava acima das declarações estaduais de que a liberdade era um direito natural. Decisões judiciais posteriores como em Prigg v. Pennsylvania e leis como o Ato do Escravo Fugitivo de 1850 confirmaram esse ponto. 0 direito de propriedade dos escravistas transcendia fronteiras e leis estaduais, com o governo federal, dessa forma, preparado para garantir o interesse pecuniário de escravistas sobre os princípios de direitos naturais e liberdade presumida. ${ }^{29}$

Menos centrada na escravidão, porém fundamental na infiltração do expansionismo escravista nas políticas e leis federais, foi a decisão da Suprema Corte de 1810 em Fletcher v. Peck. Ela subverteu a decisão legislativa da Geórgia, que visava anular a venda das terras no Alabama e Mississippi para um grupo de investidores externos no escândalo de "Yazoo". Eles compraram as terras através do governo da Geórgia sob termos altamente favoráveis, em parte por terem subornado a maior parte dos membros da legislatura estadual. A maioria dos brancos se opunha abertamente a uma venda em que o estado recebeu apenas meio milhão de dólares pelos direitos sobre 35 milhões de acres de terras. Aqui, como em todo lugar, escravistas expansionistas nem sempre concordavam entre si, muito menos com 
MAGRATH, C. Peter. Yazoo: Law and Politics in the New republic: The case of Fletcher V. Peck. WW Norton \& Company, 1967; JANE, Kamensky. Op. Cit. sulistas brancos sem escravos. Nesse caso, contudo, os tribunais apoiaram e legitimaram a aliança entre escravistas empreendedores e os mercados financeiros do Norte. Quando populistas da Geórgia tentaram invalidar a venda de Yazoo com a passagem do Expunging Act na legislatura estadual, as companhias securitizaram seus títulos de terras. Elas transformaram as ações de suas companhias em debêntures, negociadas então nos círculos financeiros do Norte e do Sul. Seu valor de mercado se escorava tanto na esperança de que o governo federal reconheceria a venda e compensaria os debenturistas com terrenos ou espécie, quanto nos ganhos esperados das terras. Isso, por sua vez, dependia da crença dos compradores de debêntures no futuro da escravidão. ${ }^{30}$

Eles acreditaram. Quando a decisão foi dada em 1810, ela ratificou a venda das terras Yazoo, consequentemente preservando a confiança nos mercados financeiros, que, por sua vez, estavam ocupados atraindo mais investimentos nas novas fronteiras algodoeiras do Sudoeste. Ela também desbloqueou a venda de milhares de acres de terras cujos títulos eram até então incertos. A decisão, no entanto, sempre atribuída ao presidente da Suprema Corte John Marshall, realizou algo ainda mais importante. Ainda que nunca tenha mencionado a escravidão, ela estabeleceu o princípio de que legislaturas não podiam anular contratos e, consequentemente, colocou a propriedade estabelecida por esses contratos além do alcance das maiorias. A Suprema Corte havia estabelecido um precedente para que qualquer comprador ou herdeiro de escravos pudesse contestar o direito de governos negarem os privilégios da escravização.

Escravistas levariam adiante a ideia de que a própria constituição protegia seus direitos a terem escravos, ainda que nesse caso tenha sido a interpretação e não o texto que serviu de justificativa. John C. Calhoun e outros expandiram a ideia de que os direitos à propriedade de escravos transcendiam o controle das legislaturas estaduais, baseados em uma prerrogativa que antecipava a doutrina clássica de devido processo substantivo da Segunda República. Como Calhoun, as famosas decisões da era Lochner insistiram que as proteções da Quinta Emenda contra o confisco de propriedades "sem o devido processo da lei" não se limitavam a isso. A linguagem da Emenda confirmava - na interpretação de Calhoun em 1840 e dos advogados do devido processo substantivo posteriormente - uma proteção mais profunda dos direitos de propriedade, presente no direito consuetudinário que precedia as constituições. Nenhuma decisão nos tribunais ou legislaturas que retirasse o direito de propriedade, especialmente de classes inteiras como magnatas industriais ou empreendedores escravistas, poderia ser justa ou constitucional.

Diversos historiadores e cientistas políticos argumentaram que os EUA pré-Guerra Civil (ou mesmo pré-1887) não possuiam algo que pudéssemos identificar como um "estado". De fato, Washington D.C. não estava repleta de extensas burocracias ocupadas por servidores públicos profissionais com o poder de regular o mercado ou a sociedade, que é justamente a ideia weberiana de estado moderno. Pesquisadores afirmam que o principal fator de longo prazo que atrasou o desenvolvimento de um estado modernizador ativo nos EUA foi a resistência de escravistas sulistas em apoiar uma fonte de poder que pudesse regular, limitar ou até mesmo abolir a escravidão. Alguns estudiosos têm colocado que o estado dos EUA era, no máximo, constituído de acordo com o modelo de "tribunais e partidos". Tribunais estabeleceram as interpretações das leis constitucionais, con- 
31

JOHN, Richard R. Rethinking The Early American State. Polity, n.40, p.332-339, julho de 2008. suetudinárias e estatutárias, regulando assim a prática. Nesse modelo, os partidos ocuparam as limitadas burocracias com esquemas de patronagem, enquanto mediavam as relações entre eleitores e legisladores. Os partidos também exerceram funções que, em um arquétipo moderno de modelo weberiano, seriam da alçada do estado. Por exemplo, quando o Secretário do Tesouro Louis McLane quis avaliar o estado de saúde e extensão das indústrias dos EUA em 1832, ele requisitou tais informações não de burocratas empregados pelo estado, mas de funcionários do Partido Democrata, espalhados pelos centros manufatureiros do Nordeste e do Médio-Atlântico. Ainda assim, o modelo de "tribunais e partidos" representa uma capacidade limitada e geralmente negativa do estado. ${ }^{31}$

Quando observamos o período pré-Guerra Civil nos EUA atentando para o sucesso de empresários que transformaram todo um subcontinente em um gigantesco campo de algodão no espaço de uma geração, a natureza e extensão do "estado" dos EUA parecem um pouco distintos do que o modelo de "tribunais e partidos" sugere. Na realidade, o estado americano era constituído de diversos aparatos, com praticamente todos apoiando a expansão, sem precedentes na história mundial, da fronteira dos EUA. Essa colonização foi realizada basicamente por empreendimentos agricolas individuais, sustentados em seus deslocamentos e sucessos pelos vultosos gastos do governo federal. Grande parte desse apoio financeiro foi destinado necessariamente à expansão dos estados escravistas, já que estes geravam de longe a maior parte das atividades mercantis da nação e utilizavam imensas riqueza nesse processo. Em um claro exemplo de ação estatal, as agências indígenas dos EUA empregaram imensos recursos, em adição ao dinheiro gasto com o estabelecimento de tratados, para removerem índios dos futuros territórios do algodão. 0 mapeamento, pesquisa, venda e financiamento anual da compra de terras também necessitava de milhares de homens. Havia ainda o sistema de correios, que encurtava as distâncias entre famílias ao facilitarem migrações, além de permitirem comunicações financeiras e comerciais de longa distância. As forças armadas protegiam as fronteiras contra incursões indígenas, destruindo, também, a única revolta escrava organizada na história da Primeira República. Sulistas impediram o governo federal de construir a maioria das estradas e canais. Eles tinham seus barcos a vapor, o governo federal gastou grandes quantias de dinheiro na limpeza de rios e melhoras nos portos, que exportavam o algodão e traziam outros bens (pagos com o dinheiro do algodão) para os EUA. Se pensarmos em todos esses esforços como constitutivos de um estado - e assim devemos fazer - então repentinamente os EUA tiveram sim um estado, que era muito mais extenso do que nós temos admitido e que se dedicou quase que exclusivamente em apoiar a expansão da escravidão.

Durante a maior parte da história da Primeira Repúlica, escravistas foram politicamente dominantes não apenas nas leis e no estado, mas nas práticas eleitorais federais - influentes o suficiente para garantir que o governo federal jamais ameaçaria a escravidão onde ela já existisse. Ainda que sulistas brancos tenham sido uma minoria da Independência em diante e famílias escravistas nunca tenham representado mais do que um terço de todos os lares do sul, durante quarenta e sete dos sessenta anos da república o país foi presidido por um dono de escravos. Escravistas controlavam metade do senado. A famosa "cláusula dos $3 / 5$ ", que contou cada escravo como o equivalente a $3 / 5$ de uma pessoa com o objetivo de distribuir proporcionalmente a representação no Congresso, também teve 
MILLER, William Lee. Arguing About Slavery: The Great Battle in the United States Congress. New York: A.A. Knopf, 1996. o efeito de fazer nortistas acreditarem que os estados escravistas estavam super-representados. Estivessem ou não, o fato permanece de que estados escravistas controlaram pelo menos $40 \%$ da Câmara durante a maior parte da Primeira República e uma porcentagem ainda maior dos votos eleitorais. Como os estados do Norte constantemente se dividiam a respeito de questões como política tarifária ou abertura para imigrantes, políticos sulistas podiam demandar que seus aliados nos estados livres apoiassem as politicas de expansão da escravidão sob risco de perderem qualquer esperança de vencer as eleições nacionais. Quando figuras de base passaram a criticar a escravidão sulista através de petições enviadas ao Congresso na década de 1830, muitas de suas reclamações se centraram no tráfico doméstico de escravos e na possibilidade de os EUA anexarem a recém fundada república escravista do Texas. Escravocratas convenceram seus aliados a cooperarem com a eliminação desses elementos essenciais da expansão escravista das discussões no Congresso, ainda que muitos acreditassem que o direito à petição fosse um compromisso fundamental de qualquer governo, especialmente um representativo. ${ }^{32}$

Como consequência da dominação política por expansionistas-escravistas, politicas federais consistentemente permitiram e apoiaram o crescimento da Segunda Escravidão nos EUA. A compra da Louisiana em 1804 abriu o baixo Vale do Mississippi ao crescimento de um imenso complexo de algodão e escravidão. Os War Hawks, em sua maioria na fronteira da escravidão, forçaram os EUA a entrarem na guerra de 1812 na esperança de conseguirem mais territórios. Eles tiveram a sorte de ver a Louisiana escapar intacta da guerra enquanto forçavam imensas concessões de grupos indígenas no Alabama e na Georgia. Em 1819-20, o apoio federal à invasão da Flórida por Andrew Jackson finalmente resultou na aquisição daquele território, uma das metas dos war hawks em 1812. Ainda que John Quincy Adams, que não era senhor de escravos, tivesse vencido a contestada eleição de 1824, sua presidência fracassou. 0 malogro foi causado pela oposição de escravistas sulistas a questões como o reconhecimento do estado do Haiti e, acima de tudo, pela recusa deles em permitir que indígenas permanecessem em qualquer terra propícia ao crescimento de algodoeiros. Enquanto a eleição de Andrew Jackson tem sido celebrada por historiadores como a vitória do homem comum, seu discurso de posse prometia a aquisição de mais terras indígenas (provavelmente nos estados escravistas), 0 ajuste das tarifas em favor de escravocratas sulistas e a expansão em direção ao território texano do México.

Jackson é evidentemente reconhecido como um dos fundadores do Partido Democrata, que na maior parte de sua história foi o único partido realmente nacional nos EUA. Seria impossível para ele dominar a política do período entre os Pânicos de 1819 e 1837 sem o amplo apoio de nortistas e sulistas brancos sem escravos. Ele satisfez alguns de seus desejos, incluindo o anseio por uma política mais participativa. Isso não era exatamente o que elites sulistas queriam. Jackson, no entanto, demonstrou como um estilo populista combinado com políticas específicas poderiam ser travestidos de anti-elitistas enquanto simultaneamente beneficiavam a expansão empreendedora da escravidão. Em sua "guerra" contra o Segundo Banco dos EUA, por exemplo, Jackson descreveu sua desestabilização unilateral do banco central do país, principal condutor de fundos de investimentos estrangeiros, como a decapitação democrática de uma "hidra" maligna que ameaçava a masculinidade dos homens simples que o 
apoiavam. Ainda assim, ele e sua administração também transformaram a desestabilização do B.U.S. em novas oportunidades para lucros empresariais na fronteira escravista.

Durante boa parte da Primeira República, escravistas e seus líderes políticos geralmente conseguiram construir coalizões por trás de políticas que satisfizessem seus desejos. Mesmo quando estilos políticos mudaram e se tornaram substancialmente mais democráticos para homens brancos, a expansão geográfica dos EUA em combinação com os lucros da expansão escravista implicavam que a distribuição política de recompensas não era necessariamente um jogo de soma zero. A remoção de índios durante a administração de Jackson, por exemplo, criou inúmeras oportunidades para especuladores e fazendeiros ao mesmo tempo que abriu imensos territórios para aspirantes a pequenos proprietários rurais, que podiam encontrar terras livres e comprá-las por preços mínimos. Talvez a perspectiva de que as políticas do Partido Democrata foram em si mesmas positivas para democratas da classe trabalhadora nortista seja exagerada. A derrota dos interesses de elites bancárias pouco os ajudou e booms nos mercados de terra do Oeste também foram de pouca valia, exceto se para lá tivessem se deslocado. Ainda assim, imigrantes irlandeses, trabalhadores brancos nascidos nos EUA e outros que foram levados às urnas pelos Democratas no auge do, assim chamado, Segundo Sistema Partidário, foram recompensados psicologicamente por estarem do lado vencedor. Líderes democráticos do Norte como Martin Van Buren, que acreditava que uma aliança Norte-Sul era necessária para prevenir os EUA de se tornar uma sociedade antidemocrática e aristocrática, conscientemente submeteu os interesses de brancos nortistas aos de seus aliados sulistas até os últimos anos de sua carreira. Os Whigs do Norte precisavam desesperadamente que sulistas votassem em seu partido, tendo que evitar, portanto, as acusações mortais acerca de supostas inclinações abolicionistas.

Lealdades partidárias tinham maiores chances de criar divisões entre nortistas do que entre sulistas, especialmente quando as fichas mais valiosas estavam em jogo. Quando a expansão da escravidão esteve ameaçada, escravistas formaram um bloco único. Assim o foi, por exemplo, durante a Crise do Missouri de 1819. Se políticos e eleitores dos estados livres tivessem feito o mesmo, seus números teriam permitido que a duradoura fronteira do escravismo fosse fechada. Contudo, não havia políticos e eleitores suficientes nos estados livres empenhados em resistir. Muitos concluíram ter interesses próprios (ainda que não homogêneos) na Segunda Escravidão. A maioria se filiou ao Partido Democrata, que apoiou mais consistentemente a expansão da escravidão. Nas últimas décadas, historiadores norte-americanos têm olhado para as formas com que brancos nortistas, tanto imigrantes quanto nascidos no pais, utilizaram o racismo para legitimar suas demandas por igualdade democrática com os bem nascidos e privilegiados. Para construir uma ideologia que justificasse a branquitude (masculina) enquanto única forma de admissão no sistema político, eles insistiram que negros livres fossem proibidos de votar e transformaram os shows de menestréis blackface em um estilo cultural consumivel que ridicularizava aqueles que eram imitados. Esses homens brancos tenderam a votar nos democratas. A conclusão dos estudos sobre a "branquitude" aponta que eles votavam dessa forma em troca de um capital psicológico que lhes dava uma sensação de superioridade. 0 que tem sido menos estudado é o capital real que esses brancos podiam ganhar com o cres- 
ROEDIGER, David. The Wages of Whiteness: Race and the Making of the American Working Class. New York, London: Verso, 1991; MAY, Robert E. The Southern Dream of a Caribbean Empire, 1854 1861. Baton Rouge: Louisiana State University Press, 1973.

FONER, Philip. Business and Slavery: The New York Merchants and the Irrepressible Conflict. Chapel Hill: The University of North Carolina Press, 1941; BRAUER, Kinley J. Cotton Versus Conscience: Massachusetts Whig Politics and Southwestern Expansion. Lexington: University of Kentucky Press, 1967 cimento da escravidão. Muitos brancos da classe trabalhadora no Norte livre esperavam tirar vantagem das oportunidades que surgiriam de novas conquistas. Seu apoio às expedições "filibusteiras" que propunham anexar Cuba à União foi notório. ${ }^{33}$

Enquanto isso, fora das cidades do Nordeste, praticamente todo o setor agricultor dos estados livres do Noroeste em torno de 1830 (Ohio, Indiana e lllinois) dependia do comércio com estados escravistas através do Rio Mississippi. Em tempos de rápida expansão, campos de trabalho escravo se especializaram em produzir algodão, com empreendedores deixando a produção de milho e a criação de porcos a cargo dos agricultores livres do Noroeste, de quem poderiam comprar os suprimentos necessários. Esses mercados foram cruciais para o desenvolvimento da economia desses estados livres. Tão importante quanto o apoio de fazendeiros do Noroeste e da classe trabalhadora urbana do Nordeste, foi o interesse de diversas elites nortistas na expansão da escravidão. Isso não surpreende, já que a escravidão sulista esteve no centro da economia do Nordeste até a Guerra Civil. Magnatas do algodão, comerciantes e banqueiros nas cidades de Nova lorque e Filadélfia e empregadores manufatureiros tenderam a apoiar políticas pró-Sul até pouco antes da Guerra. Expansionistas sulistas tinham diversos aliados nortistas, muitos dos quais possuiam enormes interesses financeiros diretamente ligados à expansão escravista. Essas pessoas foram fundamentais na mediação das tensões entre os receios nortistas com a dominação sulista e os desejos expansionistas do Sul. Havia exceções como os irmãos Tappan, comerciantes ricos que, apesar de venderem suprimentos para o Sul, financiaram o desenvolvimento de um movimento abolicionista da década de 1830 em diante. Para cada exemplo desses, entretanto, há outro como August Belmont, um financista de Nova lorque que apoiava os planos de anexação pró-escravista de Cuba nos anos de $1850 .{ }^{34}$

Escravistas e seus aliados brancos sem escravos do Sul, portanto, dominaram a política federal. Por sessenta anos, eles conseguiram utilizar sua capacidade de união regional para convencer nortistas a se juntarem a eles em uma coalizão forte o suficiente para alcançar resultados expansionistas-escravistas. Começava então o último episódio de inovação financeira no período anterior à Guerra Civil. Esse seria diferente, já que as forças econômicas, sociais e demográficas liberadas pelas destruições criativas de especuladores afrouxaram as amarras políticas da Primeira República. 0 balanço de forças no estado e sua orientação em apoio à expansão contínua da economia algodoeira em todas as suas variantes permaneceram iguais em aspectos decisivos, mesmo quando o mapa da nação expandia.

\section{Era IV}

Ao longo dos anos 1840, sulistas ainda se recusavam a pagar o que eles, de acordo com alguns, roubaram dos investidores de fora da região. Grandes instituições como os Baring Brothers não pretendiam arriscar muito capital, novas instituições financeiras não surgiram no lugar das que haviam desaparecido com a crise da Era III no Sul e estados não tinham capacidade de fazer empréstimos em grande escala. Um dos resultados foi a diminuição dos investimentos em infraestrutura no Sudoeste. Antes de 1840, bem como após 1850, construções de ferrovias no sul ocorriam com a mesma rapidez que no resto do país. A expansão da malha ferroviária no Sul, no entanto, não ocorreu durante a década de 1840, mesmo enquanto aumentava rapidamente em outras partes do país. 0 motivo foi a ausência de 
CRONON, William. Nature's Metropolis: Chicago and the Great West. New York: W.W. Norton, 1991.

WOODMAN, Harold. King Cotton's Retainers: Financing and Marketing the Cotton Crop of the South, 1800-1925. Lexington: University of Kentucky Press, 1968; MARTIN, Bonnie. Slavery's Invisible Engine: Mortgaging Human Property. Journal of Southern History, v.76, n.4, p.817-866. financiamento e a consequência foi o déficit de longa duração das linhas ferroviárias na região em comparação com os estados livres. Para completar, em 1850, empreendedores de Chicago tiraram vantagem do enfraquecimento repentino de Nova Orleans - a cidade que havia sido marcada nos anos 1830 pela mais densa concentração de capacidade bancária do país para tomar o controle de boa parte das redes comerciais na região norte do Vale do Mississippi. ${ }^{35}$

De modo geral, empreendedores escravistas sulistas vivenciaram os anos 1840 como uma constante perda de controle sobre seus próprios destinos financeiros, uma sensação de perda que crescentemente moldou suas visões de mundo. Eles passaram a se verem como excluidos e estigmatizados, uma perspectiva que era evidentemente potencializada pelas marteladas retóricas do pequeno, porém barulhento, movimento abolicionista. Mesmo após a subida nos preços do algodão em fins da década de 1840 - uma onda que persistiu durante toda a década seguinte, no mais longo período de preços altos em toda a era pré-Guerra Civil - escravistas aumentavam suas reclamações. Em seus jornais e revistas eles se queixavam da exploração de seus próprios parceiros comerciais, que os forneciam crédito e mercados.

Eles certamente tinham muito menos controle sobre suas próprias finanças - muito menos do que quando eles mesmos imprimiam suas obrigações e comandavam os bancos, decidindo o quanto emprestar a si mesmos e a seus parentes, e quando cobrar (ou, mais frequentemente, não cobrar) os pagamentos. Mas eles não estavam sem crédito. Arcar com os gastos anuais dos campos de trabalho escravo no Sul algodoeiro e investir em sua expansão continuava sendo a tarefa anual de uma imensa máquina financeira. Agora, contudo, o crédito chegava aos escravistas através de um novo sistema de organização. Bancos comerciais emprestavam dinheiro aos factors - negociantes do Nordeste baseados em Nova lorque ou Boston, mas com escritórios em Nova Orleans, Mobile, etc. Factors, por sua vez, emprestavam aos fazendeiros, geralmente com a garantia de hipotecas individuais em escravos registradas e asseguradas por tribunais locais. Fazendeiros geralmente emprestavam dinheiro para produtores de algodão de menor escala, que hipotecavam seus escravos e geravam um verdadeiro sistema capilar de distribuição de crédito e garantias. 0 sistema gerou não apenas algodão, que prosseguiu sendo a mercadoria base do comércio no mundo industrializado. Ele também explorou uma vasta reserva de garantias - talvez a maior reserva desse tipo em todo o mundo ocidental - representada pelos escravos sulistas. Mas escravistas não controlavam esse sistema e sabiam disso. ${ }^{36}$

Nos anos 1850, outras 250.000 pessoas escravizadas foram deslocadas dos velhos para os novos estados. 0 tráfico de escravos que arrastou todas essas pessoas também mudou e incorporou linhas ferroviárias e 0 telégrafo. Essas mudanças reduziram a arbitrariedade das oportunidades e levaram muitos negociantes a adotarem um modelo em que eles simplesmente consignavam pessoas escravizadas de um mercado a outro, de um vendedor a um comprador, não assumindo os riscos de serem seus donos durante seu transporte do Sudeste para o Sudoeste. Os migrantes forçados de uma nova geração se juntaram aos filhos das anteriores e abriram novas áreas imensas para o algodão: os campos de dez milhas ao norte do delta do Mississippi, ao sul de Memphis, as matas a leste do Texas, os condados do outro lado do rio de Natchez. Se em meados dos anos 1840 os EUA 
SILBEY, Joel H. Storm Over Texas: The Annexation Controversy and the Road to the Civil War. New York: Oxford University Press, 2005. produziam entre 1.5 e 2.1 milhões de fardos de algodão por ano, em 1860 a produção subiu para 4.5 milhões. 0 enorme volume revela a persistente eficiência da whipping-machine, explorando a criatividade e habilidades de cada mão individual. As cotas de muitos campos de trabalho haviam passado das 200 libras por dia e cada "mão" se tornava mais valiosa do que nunca.

Depois das grandes reviravoltas de fins dos anos 1830, no entanto, empreendedores estavam tensos. Eles queriam recomeçar o rápido crescimento. Em períodos de expansão, investidores e credores se empolgavam. Inovações financeiras apareciam e tornavam a oferta de crédito amplamente disponivel para escravistas nas fronteiras do Sudoeste. Oportunidades de lucros estavam por toda parte. Não era coincidência, por exemplo, que muitos dos mais ardentes defensores da anexação da república independente do Texas fossem justamente aqueles que haviam comprado suas debêntures desvalorizadas por alguns centavos. Eles calculavam que o governo dos EUA as compensariam em seu valor total. Então, de 1843 a 1846, líderes políticos sulistas manipularam e convenceram democratas nortistas a apoiarem não apenas a anexação de o imenso novo império para a escravidão que era o Texas, mas uma guerra expansionista-nacionalista contra o México. ${ }^{37}$

Em 1846, algo inusitado aconteceu, ainda que o evento já estivesse sendo gestado desde a crise da Era III. 0 ressentimento do Norte em relação à depressão econômica causada pela especulação sulista e à resistência de empreendedores-escravistas em sanarem as dividas de suas aventuras individuais ou dos esquemas financeiros de suas comunidades, aumentava. Esse sentimento começava a destruir as coalizões inter-regionais que escravistas conseguiram estabelecer em favor de objetivos expansionistas-escravistas. Quando David Wilmot, um político democrata do Norte, propôs em 1846 que nenhum dos territórios tomados do México deveriam se tornar estados escravistas, ele catalisou o medo latente nos estados livres de uma dominação sulista. Insistindo nela durante quatro anos, a posição de Wilmot resultou na passagem do Compromisso de 1850. A curto prazo, pelo menos, a escravidão não invadiria a Califórnia. Sulistas indignados falavam de secessão, enquanto os votos no Congresso não seguiam mais padrões partidários havia quatro anos. Os dois principais partidos se fragmentavam com as pressões e os Whigs, de fato, desapareceriam dentro de três anos.

Os persistentes compromissos que tornaram possivel a Primeira República enfim tremiam. Havia muitas causas para a resistência nortista não estar mais no mesmo ritmo que permitiu a domesticação de sua força política pelos interesses escravistas. Além do ressentimento de nortistas em relação à falta de confiança financeira nos sulistas, em um nivel estrutural as economias do Norte se tornaram mais diversificadas e menos dependentes das mãos catadoras de algodão como motor de crescimento. Havia ainda mais uma razão, a crescente insistência entre sulistas de que nortistas deveriam abraçar uma versão da Primeira República que era ainda mais explicitamente comprometida com a expansão eterna da escravidão. Calhoun e aqueles que levaram adiante seu legado após sua morte em 1850 trabalharam intensamente para forçar o governo federal a incorporar proteções afirmativas à escravidão por toda parte - incluindo nos estados livres e, definitivamente, em todos os territórios - em todos os seus compromissos. Insatisfeitos com a disposição dos Democratas em adquirir Cuba, sulistas expansionistas 
E.g. FLETCHER, George. Our Secret Constitution: How Lincoln Redefined American Democracy. New York: Oxford University Press, 2001.

39

FONER, Eric. Nothing But Freedom: Emancipation and Its Legacy. Baton Rouge: Louisiana State University Press, 1983. demandaram que o partido se comprometesse a subverter o Compromisso do Missouri em 1854. Em 1857, Democratas sulistas e seus aliados nortistas na Suprema Corte declararam que a escravidão não poderia ser barrada em qualquer território e abriram as porteiras para uma ainda maior expansão. Em 1860, escravistas destruíram o único partido nacional remanescente, o Democrata, com a polêmica acerca do comprometimento do partido em transformar todo o Oeste em uma nova versão do Mississippi.

Então, como diz uma famosa descrição, a guerra chegou. A Segunda Escravidão foi a base da Primeira República, que durou até sua dissolução em 1861, após uma dolorosa secessão. De certa forma, o que os escravistas fizeram para levar a Primeira República ao fim foi, na verdade, tentar reestabelecer uma versão mais antiga - ou uma versão particular - daquela república em uma realidade que havia sido transformada ao longo de setenta anos por suas próprias práticas de inovação, produção de lucros e exploração. Uma coisa era certa: os EUA que emergiram dos escombros da guerra e da emancipação eram radicalmente distintos daquele dividido pelos secessionistas.

0 que poderia ter sido mais tumultuado do que os anos entre 1861 e 1865 nos EUA? 0 que foi mais destrutivo do que o fim, trazido pela guerra e pela política, de um tipo de direito à propriedade que, desde a fundação da república, líderes políticos insistiram ser a condição sine qua non da participação sulista na União? E, claro, o sistema de contabilidade daqueles direitos de propriedade, um tipo de medida que foi ele mesmo eliminado pela guerra, colocava os direitos de propriedade em escravos como a maior pilha de dinheiro da república. Tudo aquilo - riqueza, convenções políticas fundadoras, categorias legais, o motor da mais rápida expansão econômica e geográfica da história humana - acabou em quatro anos. Tudo foi substituído não só por uma nova distribuição do poder político-econômico, mas por revisões constitucionais tão significativas que alguns as descreveram como sendo uma nova constituição. ${ }^{38}$ De fato, a transformação em relação ao período pré-Guerra Civil foi tão dramática que nós deveríamos nos referir a ela como uma transição da Primeira para a Segunda República.

A transição foi da Primeira República e Segunda Escravidão, de onde surgiu a Primeira Revolução Industrial, à Segunda República, emancipação (que implicou em "nada além da liberdade", como no lembrete ambíguo de Eric Foner) e a Segunda Revolução Industrial..$^{39}$ Essa foi a grande transformação da história dos EUA. Ao contarmos a história nesse esquema, podemos escapar de um padrão estabelecido nas histórias convencionais do país que trata a existência da escravidão como uma contradição trágica que foi finalmente resolvida. Essa construção confortável nos assegura que a solução correta sempre esteve presente e que a essência do projeto americano nacional foi essencialmente libertário.

Esse impulso é falso. A história nacionalista quer que os leitores acreditem que o passado é um todo, que não houve ruptura da fundação até o presente. Uma vez que aceitamos o fato de que a refundação após 1861 acabou com a Primeira República e deu a luz a uma nação fundamentalmente diferente que merece a designação de Segunda República, nós conseguimos enxergar a amplitude e profundidade da ruptura. $\mathrm{E}$ quando olhamos para o outro lado do abismo, nós vemos finalmente 0 quão distinto era o terreno da Primeira República e da Segunda Escravidão. Podemos reconhecer a desolação que lá estava, o deserto que foi atraves- 
NORTHUP, Solomon. Op. Cit., p.308. Eu adapte os dialetos mais estereotipados. sado por um milhão de migrantes forçados em direção a primaveras cada vez mais secas. Nós podemos entender o quão poderosas eram as armadiIhas nas quais pessoas escravizadas ficaram presas e o quão implacáveis e unificadas eram as forças que tornaram a liberdade para elas uma exceção ao invés da regra. Finalmente, então, podemos entender um pouco o que Patsey sentiu no dia em que o branco de Nova lorque apareceu para libertar Solomon Northup, conhecido por ela como Platt, de seus doze anos de cativeiro. Patsey - que "dançava" nos campos, era a melhor catadora do campo de trabalho escravista, e, ainda assim, a que mais açoitamentos sofria (para que ela coletasse ainda mais velozmente e servisse de exemplo para todo o resto) - "veio de trás de uma casinha e jogou seus braços ao redor de meu pescoço. 'Oh! Platt', ela gritou, com lágrimas escorrendo por seu rosto, 'você será livre - você irá para um lugar distante e nós nunca mais veremos você. Você me salvou de muitas chicotadas, Platt; eu estou feliz que você será livre - mas oh! Deus, Deus! 0 que será de mim?" ${ }^{40}$ Ela não tinha motivos para acreditar que veria o fim, e talvez nunca o tenha visto de fato.

Tradução: Leonardo Marques 